\title{
Klasifikácia a funkcia komunitných záhrad v meste (prípadová štúdia z Bratislavy) ${ }^{1}$
}

\author{
Petra Hencelová ${ }^{2}$ - František Križan - Kristína Bilková ${ }^{3}$ \\ Katedra regionálnej geografie, ochrany a plánovania krajiny, PriF UK, Brati- \\ slava \\ Geografický ústav SAV, Bratislava
}

\begin{abstract}
Classification and Function of Community Gardens in the City (Case Study from Bratislava). The paper focuses on the identification and classification of community gardens in the Bratislava. It concerns a pilot study focused on community gardens in Bratislava (Slovakia). Community gardens in a post-socialist city can be considered a modern phenomenon despite the fact that urban gardening was present in the city even during the communist regime in the form of allotments gardens and garden colonies. The main methods used to research community gardens include a questionnaire survey of members of community gardens and semi-structured interviews with administrators of community gardens. Different classification criteria (location, size, number of members, and ownership) are used in the paper to identify community gardens. Although the primary function of community gardens in Bratislava is the food production, formation of communities also plays an important role.

Sociológia 2020, Vol. 52 (No. 1: 51-81)

https://doi.org/10.31577/sociologia.2020.52.1.3
\end{abstract}

Key words: Community gardens; classification and function; urban agriculture; Bratislava

Úvod

Alternatívne potravinové siete zahŕňajú rôznorodé prepojenia producentov, spotrebitel'ov a d'alších aktérov ako alternatívu ku konvenčným potravinovým siet’am rozvíjajúcim sa pod vplyvom globalizácie v maloobchode a spotrebe. Alternatívne potravinové siete vznikli ako dôsledok „nasýtenosti“ spotrebitelov, účastníkov globálneho potravinového systému a ich konvenčného správania. (Goodman 2004) Alternatívne potravinové siete majú za ciel' byt' ekonomicky životaschopné pre pol'nohospodárov (producentov) a spotrebitel'ov, využívat' ekologicky vhodné výrobné a distribučné postupy a zvyšovat' sociálnu spravodlivost' a demokraciu pre všetkých členov spoločenstva. (Feenstra 1997) Watts et al. (2005) kategorizujú alternatívne potravinové siete na „slabšie“ alebo „silnejšie“ formy v závislosti od rozsahu, v akom spochybňujú zásady konvenčných potravinových sietí. Slabšie formy alternatív

\footnotetext{
1 Pod’akovanie: Autori d’akujú anonymným recenzentom za ich cenné rady, pripomienky a návrhy. Táto práca bola podporovaná Agentúrou na podporu výskumu a vývoja na základe zmluvy č. APVV-16-0232 a projektom VEGA 2/0113/19. 2 Korešpondencia: Mgr. Petra Hencelová, a doc. RNDr. František Križan, PhD., Katedra regionálnej geografie, ochrany a plánovania krajiny, Prírodovedecká fakulta Univerzity Komenského v Bratislave, Ilkovičova 6, Bratislava 84215 , Slovenská republika. E-mail: hencelova10@uniba.sk; frantisek.krizan@uniba.sk

3 Korešpondencia: Mgr. Kristína Bilková, PhD., Geografický ústav SAV, Štefánikova 49, Bratislava 814 73, Slovenská republika. E-mail: kristina.bilkova@savba.sk
} 
vychádzajú z vlastností výrobkov (spravodlivý obchod, organický názov alebo pôvod potravín). Silnejšie formy alternatív sa vyznačujú rigoróznymi prístupmi, ktoré nie sú $\mathrm{v}$ súlade $\mathrm{s}$ konvenčnými potravinovými siet’ami, sú s nimi v protiklade (komunitné záhrady, farmárske trhy, predaj z dvora, debničkový systém). Alternatívne potravinové siete možno chápat' ako budovanie nových väzieb medzi výrobcami a spotrebitel'mi a vytváranie d'alších priestorov na rozvoj nových postupov pri zabezpečovaní potravín, ktoré sú viac $\mathrm{v}$ súlade $\mathrm{s}$ ich hodnotami, normami a potrebami.

Pri členení alternatívnych potravinových sietí možno diskutovat' o kategórii, v ktorej sú producenti zároveň aj spotrebitelia. (Spilková 2016) Do tejto schémy patria aj komunitné záhrady, ktoré sú objektom výskumu tejto štúdie. Termín komunitná záhrada možno chápat' rôznorodo $\mathrm{v}$ kontexte riešenej problematiky (sociálna, environmentálna, edukačná a pod.). Vychádzajúc zo štúdií autorov Mougeot (2006) a Randolph (2011) možno komunitné záhrady definovat' ako lokality kolektívnej činnosti nachádzajúce sa na území mesta, v ktorom sa jednotlivci alebo komunita zaoberajú pol’nohospodárskou činnost’ou spravovaním nevyužitých alebo nedostatočne využívaných priestorov s ciel'om vytvárat' produkty a služby pre obyvatel'ov mesta. Je potrebné poznamenat', že nie je prijatá všeobecne akceptovatel'ná definícia termínu komunitná záhrada. (Guitart et al. 2012) Komunitné záhrady sú dôležitým prvkom mestskej mozaiky - tak v rozvinutých, ako i v rozvojových krajinách. Odlišujú sa v ponuke a dopyte podl'a lokálnych požiadaviek. Niektoré komunitné záhrady poskytujú pre členov otvorený priestor a zeleň, iné poskytujú lacné plodiny pre lokálnu komunitu, prípadne ponúkajú d’alšie funkcie alebo kombináciu viacerých.

Koncepcia komunitných záhrad pochádza z USA a ich prvotnou úlohou bolo zabezpečit' a zlepšit' potravinovú bezpečnost' v mestách, ponúknut' možnost' dopestovat' vlastné plodiny a vytvárat' organizované komunitné záhradkárske programy. (Hanna - Oh 2000; Saldivar-Tanaka - Krasny 2004; Spilková 2017) Komunitné záhrady sa viažu prevažne k mestám a reflektujú záujmy komunít $\mathrm{v}$ životnom štýle a spotrebe $\mathrm{s}$ rozvíjajúcim sa potravinovým aktivizmom. Komunitné záhrady možno taktiež považovat' za dôležitý nástroj environmentálnych skupín, neziskových organizácií a vzdelávacích klubov na obnovu a rekultiváciu urbánneho priestoru. V súčasnosti vznik komunitných záhrad reaguje na nedostatok zelene v mestách, stratu verejných priestranstiev na úkor privátnych priestorov, premenu opusteného priestoru, vytváranie príjemnejšieho prírodného prostredia alebo prepojenie lokálnej komunity s mestským pol'nohospodárstvom. (Goda et al. 2015; Borčić et al. 2016; Spilková 2017) Spoločné zdiel’anie znalosti a zručnosti, vytváranie sociálnych väzieb, stretávanie sa a budovanie susedských vzt'ahov sú dôležitými d’alšími prínosmi komunitných záhrad. (Guitart et al. 2012; Philips 2013; Randolph 2011) 
Rozvoj koncepcie komunitných záhrad v urbanizovanom prostredí mnohých postsocialistických miest (vrátane Bratislavy) nemožno považovat' za inovatívny, avšak v ostatnom období sa dá diskutovat' o renesancii záhradníckej činnosti. Prvé komunitné záhrady na území mesta Bratislava vznikli v roku 2012 a vzostupný trend zakladania komunitných záhrad nad’alej pokračuje. Dopestovanie vlastných plodín v mestských záhradkárskych kolóniách prebiehalo na Slovensku (Československu) aj počas socializmu. (Bituš́ková - Luther 2013; Spilková - Vágner 2016; 2017) Otvorené priestory v intravilánoch miest $\mathrm{v}$ čase socialistického režimu neposkytovali dostatočné priestory na pestovanie plodín v podobe záhradkárskych kolónií, a tak boli situované na predmestiach. (Duží et al. 2017) Éra socializmu zanechala záhradkárske kolónie lokalizované v pril'ahlých zónach miest, pričom súčasné komunitné záhrady sú často vsadené priamo do centra mesta. (Supuka et al. 2013)

Možno poznamenat', že záhradkárske kolónie plnili funkciu mestského pol'nohospodárstva a rodinnej rekreácie, pričom $\mathrm{v}$ nich existovali aj sociálne interakcie. Primárna produkčná funkcia bola až v priebehu vývoja (v druhej polovici 20. storočia) postupne doplnená o sociálnu funkciu. (Napr. Spilková Vágner 2016) Rozdiel medzi záhradkárskou kolóniou a komunitnou záhradou je práve $\mathrm{v}$ tom, že komunitná záhrada je vytváraná už existujúcim susedským (rezidenčným) alebo pracovným spoločenstvom, kým v záhradkárskych kolóniách toto spoločenstvo postupne vznikalo v procese sociálnej interakcie. Podl'a Exnera a Schützenbergerovej (2018) kladú komunitné záhrady ovel’a väčší dôraz na činnost' spoločenstva a pravidelné stretnutia. Sociálne vzt'ahy sú v záhradkárskych kolóniách selektívnejšie a až na výnimky nezahŕňajú časté pravidelné stretnutia. Zatial' čo komunitné záhrady sú udržiavané spoločne s ostatnými členmi komunity, pozemky záhradkárskych kolónií sa využívali individuálne. Irvine et al. (1999) zdôrazňujú, že nenútenou odozvou na procesy spojené so zvýšenou výstavbou a urbanizáciou, ktoré sú vo všeobecnosti výsledkom hospodárskeho rastu, je vznik komunitných záhrad umožňujúci mestským obyvatel'om vykonávat' záhradnícku činnost' $\mathrm{v}$ urbánnom prostredí.

V ostatnej dekáde sa záhradnícka činnost' v postsocialistických mestách rozširuje o nové perspektívy a vízie vo forme komunitných záhrad. Komunitné záhrady sa v postsocialistických mestách objavujú v druhej dekáde 21. storočia ako nové formy záhradníckej činnosti využívajúce kladný postoj k životnému prostrediu a prístupy fungovania zdola. (Goda et al. 2015) V postsocialistických mestách ako Bratislava, Praha alebo Varšava sú komunitné záhrady vytvárané zväčša iniciatívou miestnych obyvatel'ov. Medzi také možno zaradit' aj komunitné záhrady v meste L’ubl’ana, ktoré sa začali objavovat' v roku 2010. (Cvejić et al. 2015) V mad'arskom meste Szeged vznikali komunitné záhrady iniciatívou komunít od roku 2014. (Vierikko et al. 2016) Hlavným impulzom pre vznik komunitných záhrad v Prahe bolo vytvorenie lepšieho miesta, 
príjemnejšieho prírodného prostredia, premena opusteného priestoru a zmena negatívneho obrazu lokality. Väčšina pražských komunitných záhrad vznikla na nevyužívaných miestach, na pozemkoch vo vlastníctve mesta, ktoré ich prenajíma záhradkárom alebo súkromným subjektom. (Spilková 2017) Komunitné záhrady v Pol'sku slúžia nielen na uspokojovanie sociálnych potrieb používatel’ov miestnej komunity, tvorbu sociálnych kontaktov a integráciu miestnych komunít, ale aj na zvyšovanie povedomia a záujmu o mestský zelený priestor. Komunitné záhrady možno v súčasnosti nájst' vo Varšave, Krakove, Gdaňsku alebo Poznani. (Szulczewska et al. 2013; Malinowska 2015; Szczepańska - Staszewska 2016) Hodnota komunitných záhrad pre zachovanie potravinovej bezpečnosti zostáva vo Varšave sekundárnou. Skupina aktivistov vo Varšave vytvorila vertikálnu zeleninovú záhradu, aby vytvorila miesto pre sociálnu integráciu miestnych obyvatel'ov a miesto na organizovanie podujatí súvisiacich s mestským pol'nohospodárstvom. (Goda et al. 2015) Špecifickým je postsocialistické mesto Záhreb, v ktorom rozvoj nových komunitných záhrad nastal v roku 2012, ako odpoved' aktivistov na prílišnú výstavbu mestských námestí, straty verejných priestranstiev na úkor súkromných investorov, výstavbu obchodných zón a nákupných centier. Mesto Záhreb zapracovalo vo svojom novom programe čast' venovanú politike komunitných záhrad. Postsocialistický Záhreb prenajíma plochu o výmere $50 \mathrm{~m}^{2}$ zdarma tým žiadatel’om, ktorí nevlastnia a ani v súčasnosti nepoužívajú časti ornej pôdy. Komunitné záhrady slúžia obyvatel'om na produkciu zeleniny, ovocia a bylín na osobnú spotrebu. (Borčić et al. 2016)

Myšlienky vzniku komunitných záhrad na území mesta Bratislava sa začali objavovat' v roku 2012 (komunitná záhrada Projekt Život začala prvú sezónu v roku 2012, komunitná záhrada Krasňanský zelovoc začala prvú sezónu na jar 2013), čím možno trend zakladania komunitných záhrad v Bratislave porovnat' s inými postsocialistickými mestami. (Borčić et al. 2016; Dawidowicz - Lorenc 2016; Skrzypczak 2016; Spilková 2017) Medzičasom, vznik komunitných záhrad zaznamenal progresívny nárast a koncom roka 2017 bolo na území mesta Bratislava identifikovaných 11 fungujúcich komunitných záhrad (komunitná záhrada Dobrá mysel’ začala prvú sezónu na jar v roku 2018) ${ }^{4}$.

Príspevok je zameraný na tému komunitných záhrad na území mesta Bratislava a jeho ciel'om je zhodnotit' súčasný stav komunitných záhrad na území tohto mesta. Pozornost' autorov je sústredená na zmapovanie a klasifikáciu komunitných záhrad podla zvolených kritérií a identifikácia funkcií komunitných záhrad na území hlavného mesta Slovenska. Snahou autorov je diskutovat' a odpovedat' na nasledovné výskumné otázky: i) Aké je priestorové rozloženie komunitných záhrad a aké spádové zóny majú komu-

\footnotetext{
4 Medzičasom vznikla nová komunitná záhrada Kramárik. Do analýzy však nebola zahrnutá, ked’že do výskumu sa zapojili členovia a správcovia 11 komunitných záhrad na území mesta Bratislava.
} 
nitné záhrady v Bratislave? ii) Aké funkcie majú komunitné záhrady v Bratislave? iii) Sú komunitné záhrady v Bratislave otvoreným, verejným alebo privátnym priestorom? iv) Aká je motivácia členstva $\mathrm{v}$ komunitných záhradách? Ide o pestovanie plodín alebo vytváranie komunity?

\section{Komunitné záhrady: koncepty, klasifikácie a funkcie}

Mestské pol'nohospodárstvo možno definovat' ako produkciu potravín v mestách pre trh alebo domácu spotrebu. (Smit et al. 1996) Záhradnícka činnost' je považovaná za istú formu pol’nohospodárstva, takže komunitné záhrady sú formou mestského pol’nohospodárstva. (Duží et al. 2017) Úloha mestského pol’nohospodárstva sa však v čase a priestore transformuje, pričom možno diskutovat' o pol'nohospodárskom (produkčnom) a sociálnom koncepte. Záhradnícka činnost' v minulosti súvisela najmä so zabezpečovaním potravín na individuálnej alebo rodinnej úrovni, ako aj s predajom plodín na trhu prevažne pre nízkopríjmové skupiny obyvatel'ov. (cf. Borčić et al. 2016; Mudu - Marini 2018) Postupne začala byt' primárna pol’nohospodárska (produkčná) úloha záhradníckej činnosti v meste doplňovaná o rôzne vol'nočasové aktivity, pričom došlo k posunu od jednotlivca ku komunite.

V novšom ponímaní významnú úlohu pri produkcii potravín zohrávajú termíny ako udržatel'ný, ekologický, spravodlivý a pod. V tomto zmysle sú komunitné záhrady prínosom pre dosiahnutie najmä environmentálneho a sociálneho piliera udržatel'ného rozvoja a podporujú udržatel'ný prístup k spotrebe zvyšovaním povedomia o potravinách, sezónnosti, vodnom hospodárstve a individuálnom vzt'ahu k pôde. (Turner et al. 2010; Turner 2011; Middle et al. 2014; Classens 2015) Komunitné záhrady možno chápat' ako jednu z foriem ekosystémových služieb v urbánnom prostredí. Nielenže vytvárajú zelené priestory (green infrastructure), ale podporujú aj vzt’ah medzi biodiverzitou a ekosystémovými službami (napr. opelenie, zabránenie záplavám) v rámci urbánneho prostredia. (Kremen 2005; Barthel et al. 2010; Bates et al. 2011) Prispievajú k zdravému a udržatel'nému spôsobu, akým je znižovanie tepelného efektu $\mathrm{v}$ mestách a podpora prístupu $\mathrm{k}$ lokálnym plodinám. (Hardin - Jensen 2007) Záhradnícka činnost' v urbanizovanom prostredí sa všeobecne považuje za spôsob zlepšenia lokálnych potravinových dodávok, ako aj oddychových a rekreačných aktivít. (Ferris et al. 2001; Nettle 2014) Pestovaním potravín v mestách je možné zefektívnit' dodávku potravín, resp. priamo sa podiel'at' na vypestovaní plodín a pritom znižovat' environmentálne (pol’nohospodárske) náklady spojené s prepravou potravín. (Martellozzo et al. 2014) Komunitné záhrady aktívne prispievajú do mestskej produkcie potravín a do miestnych potravinových systémov, zabezpečujúce potravinovú spravodlivost' a bezpečnost' prostredníctvom zlepšenia ponuky potravín aj $\mathrm{v}$ tzv. 
„potravinových púšt’ach“5. (Baker 2004; Corrigan 2011; Sumner 2009) Tradične je primárnou funkciu komunitných záhrad pestovanie plodín. Na území hlavného mesta Bratislava (alebo Slovenska) možno diskutovat' o produkčnej funkcii ako doplnkovej funkcii zásobovania potravinami. Ide o dopestovanie vybraných potravín $\mathrm{v}$ čase pestovatel'skej sezóny. Množstvo pestovaných potravín $\mathrm{v}$ našich klimatických podmienkach nie je postačujúce pre celoročný príjem (v zmysle kvantity a variability), avšak počas pestovatel'skej sezóny vplýva produkcia potravín aj na finančnú situáciu členov komunity.

Komunitné záhrady možno považovat' za miesta sociálnej interakcie v rámci lokálnych komunít. (Nettle 2014) Záhradnícka prax využíva metódy a činnosti, ktoré nabádajú členov získavat' vedomosti a poznatky o súčasných ekologických a environmentálnych problémoch. Fungovanie komunitných záhrad vyplýva $\mathrm{z}$ angažovanosti lokálnych obyvatel'ov, pričom zjednocuje environmentálne hodnoty u členov komunitných záhrad. Prostredníctvom komunitných záhrad si členovia osvojujú praktiky, majúc povedomie o problémoch životného prostredia $\mathrm{v}$ mestách, pričom to má meratel'ný prínos na kvalitu ich života. (Krasny - Tidball 2009) Motivácia jednotlivcov zapojit'sa do mestských pol'nohospodárskych aktivít je rôznorodá. Medzi najčastejšie patria rôzne sociálne programy, potravinová bezpečnost', ekonomické a environmentálne dôvody alebo prínosy pre l'udské zdravie. (Armstrong 2000; Okvat - Zautra 2011; Block et al. 2012)

Dynamicky narastajúci počet príspevkov $\mathrm{k}$ téme komunitné záhrady dokumentuje všeobecný trend záujmu o výskum komunitných záhrad. Evidujeme množstvo štúdií diskutujúcich o komunitných záhradách $\mathrm{v}$ prípade mnohých vedných disciplín, odlišných metodických postupov alebo rôznych klasifikačných kritéríi. (Guitart et al. 2012) V tomto príspevku sa niektorými z nich zaoberáme. Dôležitým klasifikačným kritériom je poloha komunitných záhrad. Lokalizácia komunitných záhrad môže mat' vplyv na dostupnost' potravín pre vybrané skupiny obyvatel'stva (Wang et al. 2014) alebo aj na cenu nehnutel'ností. (cf. Voicu - Been 2008) K d’alším základným klasifikačným kritériám patrí vel'kost' komunitnej záhrady. Drake a Lawson (2015) upozorňujú, že vel'kost' komunitných záhrad (podl'a rozlohy) môže ovplyvnit' potreby komunity (malé záhrady pocit'ujú nedostatok miesta, vel'ké záhrady upozorňujú na príliš rozl'ahlú vol'nú lokalitu). Vel'kost' komunitnej záhrady možno hodnotit' aj počtom členov. Ciel’om správcov komunitných záhrad je získat' čo najväčší počet aktívnych členov, ktorý je však limitovaný. Od počtu členov závisia okrem financií aj aktivity komunity a samotný chod komunitnej záhrady. Vlastnícke pomery patria medzi d’alšie klasifikačné kritérium, ktoré možno považovat' za dôležitý faktor ohrozujúci fungovanie komunitnej

\footnotetext{
5 Potravinové púšte, ang. „food desert“ sú územia, kde majú spotrebitelia obmedzený prístup k cenovo dostupnejším a zdravým potravinám, s menej priaznivou dostupnost'ou vel'kometrážnych predajní potravín. (Wang et al. 2014)
} 
záhrady. Autori Eizenberg (2013) alebo Drake a Lawson (2015) rozlišujú súkromné vlastníctvo, prenajaté vlastníctvo alebo vlastníctvo pozemku samotnej komunitnej záhrady. Vzhl'adom na využitie nezastavaných pozemkov v mestskom prostredí možno komunitné záhrady klasifikovat' do dvoch kategórií - mobilné a stacionárne. Pre záhradnícku činnost' v urbanizovanom prostredí v mobilných komunitných záhradách sú príznačné mobilné nádoby rôznych vel'kostí. Prednost'ou tohto typu komunitných záhrad je ich premiestnitel'nost', dočasné využitie priestoru $\mathrm{v}$ čase a žiadna stála viazanost' na pozemok záhrady. Mobilnú komunitnú záhradu možno označit' aj ako „take away“ záhrada. (Bendt et al. 2013) Vychádzajúc z definície komunitných záhrad ide vo všeobecnosti o otvorené priestory. Termín „otvorený priestor“ je v prípade komunitných záhrad chápaný rôznorodo. Kurtz (2001) rozlišuje oplotené a zamknuté komunitné záhrady, chránené pred vandalizmom a krádežami. Iné záhrady majú obmedzený čas prístupu širokej verejnosti a v konečnom dôsledku existujú komunitné záhrady neoplotené. Preto vnímanie komunitných záhrad ako otvorených, verejných prípadne súkromných priestorov varíruje a nie je jednoznačne definované.

Funkcie komunitných záhrad vychádzajú z konceptov ich zakladania postavenom na pestovaní plodín. Okrem toho však komunitné záhrady majú mnoho d’alších a rôznorodých funkcií s výrazným dosahom na komunitu a spoločnost'. Komunitné záhrady napomáhajú rodinám zlepšit' potravinovú sebestačnost', zabezpečit' prísun čerstvých potravín $\mathrm{v}$ čase pestovatel'skej sezóny a vylepšit' finančnú situáciu. Vzájomná výmena znalostí a zručností, vytváranie sociálnych väzieb, stretávanie sa a budovanie susedských vzt'ahov sú dôležitými vedl'ajšími funkciami komunitných záhrad (Randolph 2011; Guitart et al. 2012), ktoré mnohí členovia komunitných záhrad považujú za ich primárne funkcie. Ako tvrdí Philips (2013), vedlajším prínosom pestovania plodín, často dôležitejším ako záhradnícka činnost', je zoznámenie sa s odlišnými kultúrami, skrášlenie prostredia, nadviazanie kontaktov alebo rozvoj komunity. Firth et al. (2011) poukazujú na budovanie kohézie v komunite, premostenie vzájomných väzieb a prepájanie sociálneho kapitálu. Armstrong (2000) uvádza, že komunitné záhrady prispievajú k mentálnemu duševnému zdraviu a podporujú fyzickú aktivitu členov. Agustina a Beilin (2012) vnímajú komunitné záhrady v austrálskom Melbourne ako priestory pre migrantov, $\mathrm{v}$ ktorých majú imigranti možnost' prispôsobit' sa hostitel'skej krajine pri zachovaní svojej kultúrnej identity. Ferris et al. (2001) a Kingsley et al. (2009) označujú terapeutické komunitné záhrady ako lokality pre liečbu duševného zdravia a duchovnosti. Ferris et al. (2001) alebo Walter (2013) rozlišujú vzorové komunitné záhrady majúce funkciu výukových centier. Takéto komunitné záhrady sú určené pre potreby neformálneho vzdelávania a poskytujú komunitám poradenstvo. Iné komunitné záhrady majú edukačno- 
výchovnú funkciu a spolupracujú s vedeckými i vzdelávacími inštitúciami. Prispievajú $\mathrm{k}$ rozvoju alternatívneho potravinového systému a vedomostí o výživových konceptoch vzt’ahujúcich sa na pestovanie plodín. (Ozer 2007)

\section{Metódy a dáta}

Zámerom autorov bolo zmapovanie komunitných záhrad na území mesta Bratislava a ich analýza cez prizmu poskytovaných funkcií a vybraných klasifikačných kritérií. Prvým krokom výskumu bolo vytvorenie databázy komunitných záhrad v Bratislave, ked’že takáto databáza doposial' nebola publikovaná a v rôznych inštitucionálnych dokumentoch (vrátane plánovacích) absentuje. Identifikácia komunitných záhrad na území mesta prebiehala vyhl’adávaním v prístupných zdrojoch (občianske združenia, neziskové organizácie, letecké snímky a pod.). Zozbierané informácie boli overené v teréne pre zmapovanie aktuálnej situácie s ciel’om identifikácie komunitných záhrad na území mesta Bratislava (aktuálna vs. zaniknutá, legálna vs. nelegálna komunitná záhrada a pod.).

Druhým krokom bol zber dát o komunitných záhradách a ich členoch, ktorý prebiehal troma metodickými postupmi: i) dotazníkový prieskum, ii) pološtruktúrovaný rozhovor a iii) terénny výskum s pozorovaním a fotodokumentáciou. Dotazníkový prieskum bol realizovaný s členmi aj správcami komunitných záhrad. (cf. Spilková 2017) Prvý dotazníkový prieskum bol určený pre členov komunitných záhrad $(\mathrm{n}=51)$ a bol realizovaný online využitím funkcionality Google formuláre (počas mesiacov december 2017 a január 2018). Išlo o nepravdepodobnostný zámerný výber respondentov (Rochovská et al. 2014), so zámerom analyzovat' percepcie aktívnych členov komunity starších ako 18 rokov a v tomto kontexte je potrebné dáta interpretovat'. Základné charakteristiky respondentov sú uvedené v tab. č. 1. Realizovaný dotazník bol rozdelený do troch sekcií. Po základných (všeobecných) otázkach (vek, pohlavie a pod.), nasledovala sociálna sekcia s otázkami o členstve v komunitnej záhrade a motivácii, trávení vol’ného času a aktivitách v komunitnej záhrade a pod. Poslednou bola sekcia zameraná na priestorový aspekt problematiky (adresa bydliska, spôsob a čas dochádzky do komunitnej záhrady a pod.). Druhý dotazníkový prieskum bol určený pre správcov komunitných záhrad (cf. Corrigan 2011) a bol realizovaný pri osobnom stretnutí $(\mathrm{n}=11)$. Otázky v ňom boli zoskupené do štyroch sekcií. Prvá z nich bola zameraná na základné informácie (počet členov, pohlavie, vek, rozloha pozemku a pod.). Druhá sekcia riešila fungovanie komunitnej záhrady (forma organizácie, vplyv mesta, financovanie, úloha správcu a pod.). Na členov komunitnej záhrady bola zameraná tretia sekcia. Otázky z poslednej sekcie spočívali v zhodnotení budúcnosti danej komunitnej záhrady. 
Tabul'ka č. 1: Základné charakteristiky respondentov

\begin{tabular}{ll}
\hline Charakteristiky respondentov $(\mathrm{n}=51)$ & Podiel respondentov \\
\hline Pohlavie & \\
Muž & $23,5 \%$ \\
Žena & $76,5 \%$ \\
Priemerný vek & 34,7 roka \\
Najvyššie dosiahnuté vzdelanie & \\
Vysokoškolské & $86 \%$ \\
Stredoškolské & $14 \%$ \\
Status & \\
Zamestnaný & $54 \%$ \\
Materská dovolenka & $22 \%$ \\
Samostatne zárobkovo činný & $20 \%$ \\
Študent & $4 \%$ \\
Príjem domácnosti & \\
501 až $1000 €$ & $26 \%$ \\
1001 až $1500 €$ & $32 \%$ \\
1501 až $2000 €$ & $20 \%$ \\
viac ako $2000 €$ & $22 \%$ \\
Bydlisko v Bratislave / prist'ahovaný do Bratislavy & \\
pôvodný obyvatel' & $24 \%$ \\
do 5 rokov & $12 \%$ \\
do 10 rokov & $22 \%$ \\
do 15 rokov & $16 \%$ \\
do 20 rokov & $16 \%$ \\
20 rokov a viac & $10 \%$ \\
\hline
\end{tabular}

Zdroj: vlastný výskum

Ďalším metodickým postupom zberu dát o komunitných záhradách a ich členoch vychádzal z pološtruktúrovaných rozhovorov (cf. Firth et al. 2011; Borčić et al. 2016) so správcami komunitných záhrad $(\mathrm{n}=11)$. Vo všeobecnosti možno rozhovory považovat' za najpoužívanejšiu metódu výskumu komunitných záhrad. (Guitart et al. 2012) V prípade tejto štúdie išlo o pološtruktúrované rozhovory so všetkými správcami komunitných záhrad v Bratislave počas januára 2018. Zámerom pološtruktúrovaných rozhovorov bolo zhodnotit' rozdiely vo vnútornej organizácii, forme, funkčnosti, lokalizácii komunitných záhrad, v organizácii brigád a podujatí z pohl'adu správcov komunitných záhrad. Ďalším zámerom bolo zhodnotit reflexie správcov komunitných záhrad na členov (kto sú, aké vzt’ahy prevládajú v komunitných záhradách, akým spôsobom získavajú členov, aké sú najčastejšie dôvody vystúpenia z komunity a pod.). V neposlednom rade sa výskum zameral aj na 
myšlienky a motivácie vzniku komunitných záhrad. Pološtruktúrované rozhovory trvali od 45 do 90 min a boli zaznamenané na diktafón a následne prepísané. Práve dáta $\mathrm{z}$ pološtruktúrovaných rozhovorov tvorili bázu kvalitatívneho prístupu k analýze komunitných záhrad v Bratislave. Ked’že zachovanie anonymity respondentov patrí $\mathrm{k}$ základným pravidlám etiky spoločensko-vedného výskumu, pristúpili sme $\mathrm{k}$ anonymizácii dát. (Saunders et al. 2014) Uvádzané názory a citácie správcov alebo členov komunitných záhrad sú anonymizované využívajúc klúč klasifikácie komunitných záhrad podl'a rôznych kritérií (pozri nižšie).

Tretím metodickým postupom zberu dát bol terénny výskum s pozorovaním a fotodokumentáciou komunitných záhrad. (cf. Spilková 2017) Niektoré komunitné záhrady sme navštívili viackrát, počas spoločných brigád a komunitných akcií. Zámerom terénneho výskumu bolo zhodnotit' štruktúrne (funkčné) usporiadanie komunitných záhrad a pozorovat' sociálne vzt’ahy a interakcie medzi členmi komunitných záhrad.

$\mathrm{Na}$ základe zozbieraných dát sme pristúpili ku klasifikácii komunitných záhrad na území mesta Bratislava. Pri klasifikácii komunitných záhrad bolo zámerom autorov využit' viaceré kritériá, ktoré zahŕňajú priestorové, sociálne alebo funkčné hl'adisko. Obdobné kritériá využili vo svojich prácach iní autori. (Guitart et al. 2012; Philips 2013; Spilková 2017)

\section{Klasifikácia komunitných záhrad na území mesta Bratislava}

V roku 2017 bolo na území mesta Bratislava 11 aktívne pôsobiacich komunitných záhrad. Vzhl’adom na polohu sa dajú komunitné záhrady klasifikovat' do troch skupín (obr. č. 1A): i) komunitné záhrady v historickom centre mesta, ii) komunitné záhrady vo vnútornom meste a iii) komunitné záhrady na periférii mesta. Možno konštatovat', že v Bratislave predstavujú najpočetnejšiu skupinu komunitné záhrady vo vnútornom meste. Štyri z piatich zaniknutých komunitných záhrad (mestská záhrada Sasinkova, mestská záhrada Karpatská, Záhrada pod pyramídou a komunitná záhrada Zochova) boli lokalizované v historickom centre mesta, jedna zaniknutá komunitná záhrada (komunitná záhrada Vrakunská) na periférii mesta Bratislava. Typickým znakom sú teda absentujúce komunitné záhrady v centre mesta. Len jedna aktívna komunitná záhrada je lokalizovaná na periférii mesta, v mestskej časti Devínska Nová Ves (komunitná záhrada Pri klube dôchodcov), ostatné aktívne komunitné záhrady sú lokalizované v siedmich mestských častiach vnútorného mesta. Ide o mestské časti (Dúbravka, Karlova Ves, Lamač, Nové Mesto, Petržalka, Rača, Ružinov) charakteristické bytovými domami s viacposchodovým bývaním. Akým spôsobom vnímajú správcovia komunitných záhrad lokalizáciu záhrad, vystihuje odpoved' jedného $\mathrm{z}$ respondentov: ,...záhradkárčenie nemusí byt nutne dojmom záhradkárskych osád alebo vinohradov, záhrady môžu byt aj 
v centre. Klúčová je lokalita - čím bližšie je záhrada k centru, tým väčšia šanca, že sa uchytí. Zvyšuje sa počet l'udí, ktori potenciálne bývajú v okolí, ale zároveñ sa aj zväčšuje pravdepodobnost', že miesto môže vytvárat' svoju identitu“, (správca komunitnej záhrady vo vnútornom meste, s 11-100 členmi).

Mestské časti, akými sú Jarovce, Rusovce, Čunovo, Devín, Záhorská Bystrica, Vajnory a Podunajské Biskupice sa vyznačujú rurálnym charakterom zástavby rodinných domov, bez výskytu komunitných záhrad. Lokalizácia komunitných záhrad na periférii územia mesta Bratislava má za následok nižší záujem nových žiadatel'ov o členstvo. Pre obyvatel'ov centrálnych častí Bratislavy ide o lokality, ktoré sú vnímané ako príliš vzdialené: „Vzdialenost'je velikánska prekážka. O záhrady v centre, bývalá komunitná záhrada Sasinkova, komunitná záhrada Vodárenská a čiastočne komunitná záhrada Vinica a mobilná záhrada Pionierska, majú l’udia vel'ký záujem, pretože sú stále na tej mentálnej mape Bratislavy, tým naším severovýchodným smerom je tá hranica Trnavské mýto a Račianske mýto. To čo je za touto hranicou je už Mordor, CPčkári ${ }^{6}$ a tak", (správca komunitnej záhrady vo vnútornom meste, s 11-100 členmi).

Pri realizácii dotazníkov a pološtruktúrovaných rozhovorov so správcami komunitných záhrad bol výskum zameraný aj na definovanie spádovej zóny komunitných záhrad podla členskej základne. Úlohou správcov bolo odpovedanie na nasledujúcu otázku: „Ako by ste označili Vašu komunitnú záhradu vzhladom na členskú základňu“, pričom mali na výber štyri možnosti ${ }^{7}$ : a) základná (členovia sú z blízkeho okolia, jedného sídliska); b) obvodová (členovia sú $\mathrm{z}$ okolitých obvodov, sídlisk); c) štvrt'ová (členovia sú z danej mestskej časti) a d) celomestská (členovia sú z celého mesta). Polovicu komunitných záhrad zastupujú záhrady so základnou spádovou zónou (komunitná záhrada Ostredky, komunitná záhrada Pri klube dôchodcov, komunitná záhrada Krasňanský zelovoc, komunitná záhrada Vinica a mobilná záhrada Pionierska). Možno konštatovat', že počet členov nepodmieňuje spádovú zónu komunitných záhrad. Na druhej strane, názov komunitnej záhrady často vyjadruje jej spádovú zónu (napr. názov ulice). Toto tvrdenie je platné aj pre d’alšiu kategóriu, štvrt’ovú komunitnú záhradu, kam bola zaradená komunitná záhrada v Dúbravke. Naopak, názvy komunitnej záhrady ako Cyklokuchyňa alebo komunitná záhrada Zelená Záhrada boli označené ako celomestské komunitné záhrady, ktorých členovia sú z viacerých mestských častí.

\footnotetext{
${ }^{6}$ CP-čkári je označenie pre skratku CP (cezpolnný), ktorá sa použiva pre obyvatelov dochádzajúcich do Bratislavy zo širšieho okolia.

${ }^{7}$ Členenie vychádza z klasifikácie mestskej maloobchodnej vybavenosti. (Szczyrba 2005)
} 
Obrázok č. 1: Klasifikácia komunitných záhrad na území Bratislavy
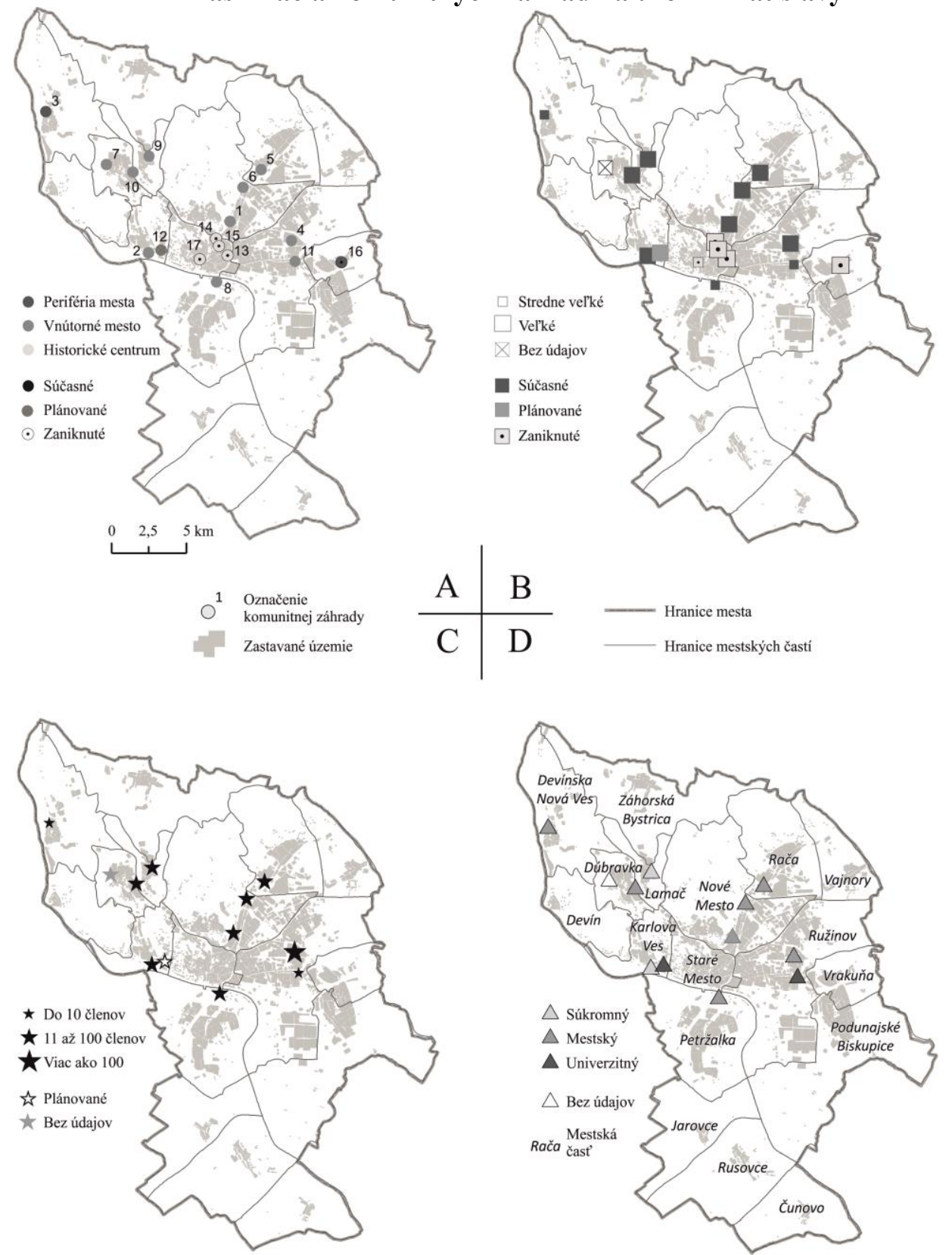

Zdroj: vlastný výskum

Vysvetlivky: A - klasifikácia podla polohy, B - klasifikácia podla rozlohy, C - klasifikácia podla počtu členov, D-klasifikácia podla vlastnickych pomerov. 
Označenie komunitných záhrad: 1 - Vinica a mobilná záhrada Pionierska, 2 - komunitná záhrada Vodárenská, 3 - komunitná záhrada Pri klube dôchodcov, 4 - komunitná záhrada Ostredky, 5 - komunitná záhrada Krasñanský zelovoc, 6 - komunitná záhrada Zelená Záhrada, 7 - komunitná záhrada Jedlé mesto, 8- komunitná záhrada Cyklokuchyña, 9 - komunitná záhrada Projektu Život, 10 - komunitná záhrada v Dúbravke, 11 - komunitná záhrada Komunitka pre každého, 12 - komunitná záhrada Dobrá mysel', 13 komunitná záhrada Sasinkova, 14 - komunitná záhrada Karpatská, 15 - komunitná záhrada Pod strechou, 16 - komunitná záhrada Vrakuňská, 17 - komunitná záhrada Zochova.

Rozlohu možno považovat' za d’alšie kritérium klasifikácie komunitných záhrad. Spilková (2017) vyčlenila tri kategórie komunitných záhrad: i) mikroprojekty (do $10 \mathrm{~m}^{2}$ ); ii) stredné vel'ké komunitné záhrady (11 až 1000 $\mathrm{m}^{2}$ ) a iii) vel'ké komunitné záhrady (viac ako $1000 \mathrm{~m}^{2}$ ). V Bratislave sa nenachádzajú komunitné záhrady prvej kategórie. Naopak, najrozšírenejšie sú komunitné záhrady s rozlohou väčšou ako $1000 \mathrm{~m}^{2}$ (75\%). Tri komunitné záhrady patria medzi stredne vel'ké. (Obr. č. 1B) Možno podotknút', že práve z kategórie vel'ké komunitné záhrady boli aj prvé vzniknuté komunitné záhrady $\mathrm{v}$ Bratislave, a to aj napriek tomu, že sa nachádzali v historickom centre mesta. Rozloha komunitnej záhrady však nepodmieňuje počet členov danej komunity.

Podl'a počtu členov možno komunitné záhrady klasifikovat' do troch skupín (Spilková 2017): i) malé komunitné záhrady (do 10 členov); ii) stredne vel'ké komunitné záhrady (11 až 100 členov) a iii) vel'ké komunitné záhrady (viac ako 100 členov). Iba jedna komunitná záhrada má do 10 členov (komunitná záhrada Pri klube dôchodcov) a iba jednu komunitnú záhradu (komunitná záhrada Ostredky) možno počtom členov zaradit' medzi vel'ké komunitné záhrady. (Obr. č. 1C) Je nutné poznamenat', že ide o počet aktívnych členov, ktorí sa aktívne podielajú na fungovaní komunitnej záhrady. Sedem komunitných záhrad má 11 až 100 členov. Treba podotknút', že až $75 \%$ správcov súhlasí s tvrdením, že počet členov komunity je obmedzený a zdôvodnený počtom boxov alebo obmedzenou plochou na pestovanie.

Vlastnícke pomery patria medzi d'alšie klasifikačné kritérium (obr. č. 1D), ktoré možno považovat' za najdôležitejší faktor ohrozujúci fungovanie komunitnej záhrady. Tak tomu bolo aj v prípade zaniknutých komunitných záhrad v Bratislave. (Tab. č. 2) Dôvody ich zániku boli rozličné, avšak previazané $\mathrm{s}$ vlastníckymi pomermi. Ide o nepredíženie nájomnej zmluvy zo strany vlastníka alebo predaj pozemku, na ktorom bola lokalizovaná komunitná záhrada, prípadne nezhodu pri ústnej dohode medzi správcoom komunitnej záhrady a riaditel’om školy a pod. Na základe výskumu možno vlastnícke pomery bratislavských komunitných záhrad rozdelit' do troch kategórií. Takmer 2/3 komunitných záhrad je lokalizovaných na mestskom pozemku a komunitné záhrady sa realizujú na základe nájomnej zmluvy s mestom (alebo mestskou čast’ou). Druhou kategóriou sú komunitné záhrady na súkromných pozemkoch. Vzt’ah $\mathrm{s}$ vlastníkom pozemku je riešený nájomnou zmluvou. Ide o dve komunitné záhrady (komunitná záhrada Vodárenská a komunitná záhrada Projekt život). 
Tretiu skupinu tvoria komunitné záhrady na pozemkoch vysokej školy, konkrétne Univerzity Komenského v Bratislave. Len jedna komunitná záhrada (komunitná záhrada Ostredky) sa nachádza na pozemku športového gymnázia, ktoré spadá pod správu kraja.

Tabul'ka č. 2: Hlavné dôvody zániku komunitných záhrad v Bratislave

\begin{tabular}{lcl}
\hline Názov komunitnej záhrady & Rok zániku & Dôvod zániku \\
\hline Komunitná záhrada Zochova & 2013 & Rozhodnutie správcu domu pestovat' okrasné rastliny \\
Mobilná záhrada Sasinkova & 2015 & Predaj súkromného pozemku \\
Záhrada Pod pyramídou & 2015 & Vypovedanie zmluvy RTVS s OZ Jedlé mesto \\
Mobilná záhrada Karpatská & 2017 & Nezrovnalosti v ústnej dohode s riaditel'kou ZŠ \\
Komunitná záhrada Vrakunská & 2017 & Nepredíženie nájomnej zmluvy \\
\hline
\end{tabular}

Zdroj: vlastný výskum

V Bratislave dominujú stacionárne komunitné záhrady, v ktorých prebieha záhradnícka činnost' bezprostredne na pôde pozemku záhrady. (Obr. č. 2 a č. 3) Iba dve komunitné záhrady možno zaradit' do kategórie mobilné komunitné záhrady (komunitná záhrada Ostredky a komunitná záhrada Vinica a mobilná záhrada Pionierska).

Obrázok č. 2: Mobilná komunitná záhrada (komunitná záhrada Vinica a mobilná záhrada Pionierska)

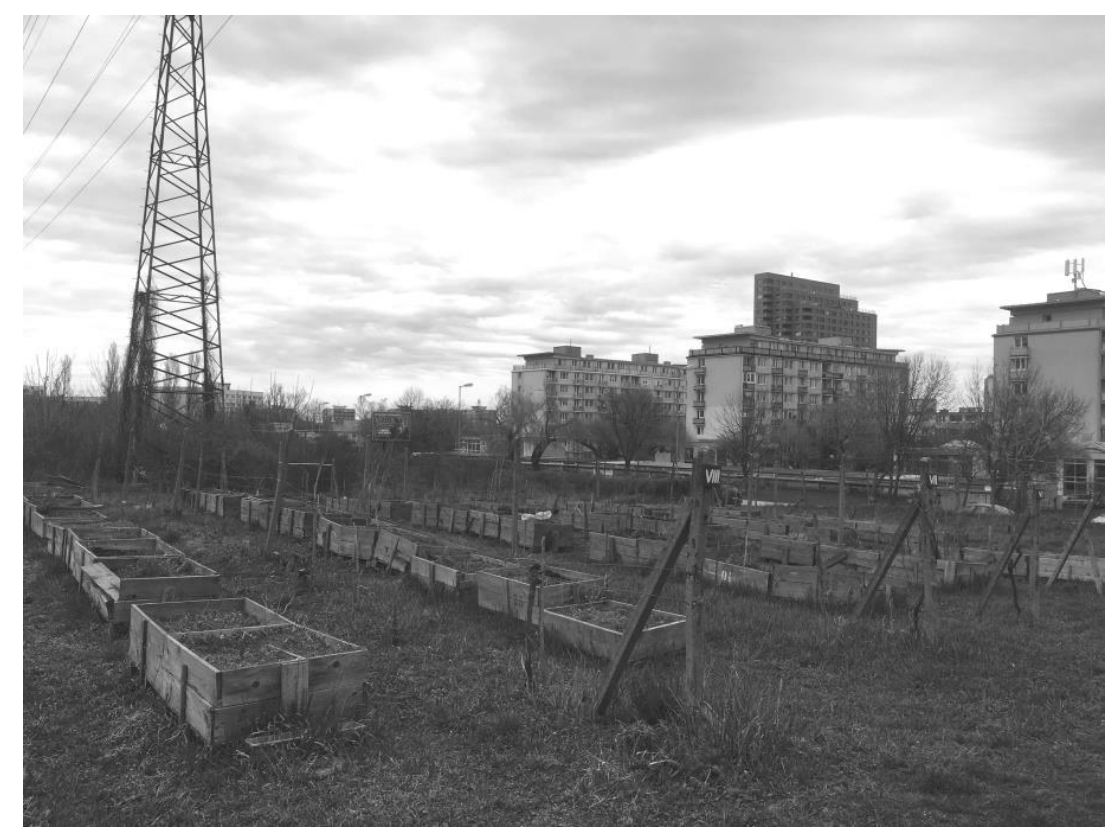

Zdroj: vlastný výskum 
Obrázok č. 3: Stacionárna komunitná záhrada (komunitná záhrada Vodárenská)

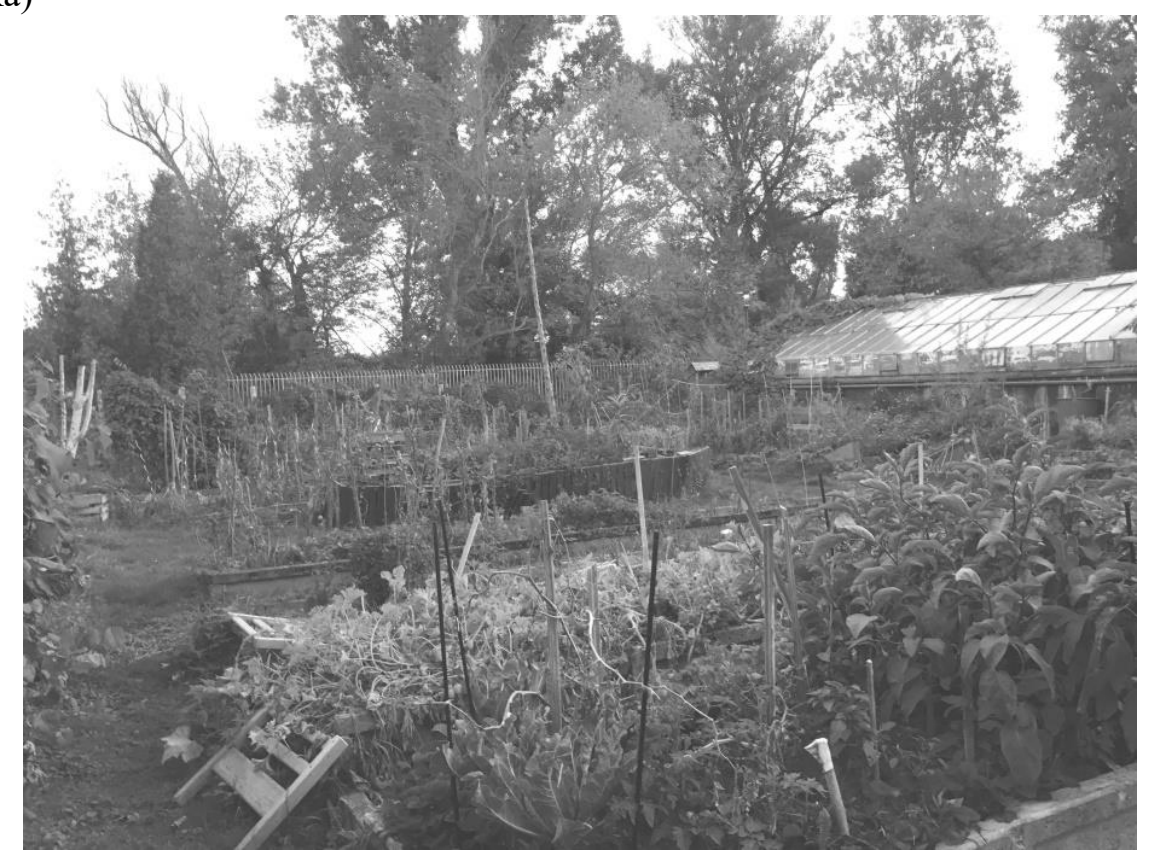

Zdroj: vlastný výskum

\section{Funkcie komunitných záhrad}

Podla požiadaviek a potrieb členov komunity vznikajú rozličné typy komunitných záhrad poskytujúce rôznorodé funkcie. Podl'a funkcií možno rozlišovat' komunitné záhrady vol'nočasové, detské a školské, výchovné, liečebné, vzorové a výstavné atd'. Rekreačnú funkciu ponúkajú všetky súčasné komunitné záhrady na území mesta Bratislava. Osem z jedenástich komunitných záhrad plní zároveň vzorovú funkciu. V komunitnej záhrade tohto typu prebiehajú workshopy alebo prednášky zamerané na pestovatel'ské zručnosti, technické zručnosti (paletové workshopy, mal'ovanie lavíc, workshopy rôznej výroby). Workshopy o permakultúre, kompostovaní, ovocinárstve, včelárstve, vinárstve a iné vedú odborníci a profesionáli a sú prioritne určené členom alebo aj širšej verejnosti. Pre niektoré komunitné záhrady je charakteristická i edukačná funkcia. Je potrebné poznamenat', že v Bratislave, ako univerzitnom meste, sa vyskytuje aj osobitý typ komunitných záhrad, univerzitné komunitné záhrady. (Hencelová 2018) Komunitná záhrada Komunitka pre každého realizovaná na Fakulte sociálnych a ekonomických vied Univerzity Komenského v Bratislave, bola v roku 2016 prvou univerzitnou komunitnou záhradou na Slovensku a 
v strednej Európe. (Drábeková et al. 2017) V roku 2017 vznikla d’alšia univerzitná komunitná záhrada - komunitná záhrada Dobrá Mysel' na Prírodovedeckej fakulte Univerzity Komenského v Bratislave, ktorá začala sezónu na jar v roku 2018. Sedem komunitných záhrad (komunitná záhrada Vodárenská, komunitná záhrada Krasňanský zelovoc, komunitná záhrada Pri klube dôchodcov, komunitná záhrada Ostredky, komunitná záhrada v Dúbravke, komunitná záhrada Dobrá mysel', komunitná záhrada Komunitka pre každého) realizuje, alebo v minulosti realizovalo spoluprácu s vedeckými a vzdelávacími inštitúciami, škôlkami, školami a sociálnymi zariadeniami. Iba jedna komunitná záhrada (komunitná záhrada Pri klube dôchodcov) bola identifikovaná ako typ terapeutickej, liečebnej komunitnej záhrady. Nachádza sa v nej čast' pozemku, ktorý majú v pláne prepožičat' združeniu, venujúcemu sa práci s týranými det'mi.

Tabul'ka č. 3: Primárna funkcia komunitných záhrad na území mesta Bratislava

\begin{tabular}{llc}
\hline Názov komunitnej záhrady & \multicolumn{2}{c}{ Primárna funkcia komunitnej záhrady } \\
\hline $\begin{array}{l}\text { Pestovanie } \\
\text { (potravinárska } \\
\text { produkcia) }\end{array}$ & $\begin{array}{l}\text { Sociálna funkcia } \\
\text { (utuženie vzt'ahov, } \\
\text { budovanie komunity, } \\
\text { využitie priestoru) }\end{array}$ \\
\hline $\begin{array}{l}\text { komunitná záhrada Vodárenská } \\
\text { komunitná záhrada Cyklokuchyňa }\end{array}$ & $\checkmark$ & $\checkmark$ \\
komunitná záhrada Zelená Záhrada & $\checkmark$ & $\checkmark$ \\
komunitná záhrada Vinica a mobilná záhrada Pionierska & $\checkmark$ & $\checkmark$ \\
komunitná záhrada Krasňanský zelovoc & & $\checkmark$ \\
komunitná záhrada Pri klube dôchodcov & & $\checkmark$ \\
komunitná záhrada Ostredky & & - \\
komunitná záhrada Projektu Život & & $\checkmark$ \\
komunitná záhrada a ovocný sad Jedlé mesto & & $\checkmark$ \\
komunitná záhrada v Dúbravke & & $\checkmark$ \\
komunitná záhrada Dobrá mysel' (PriF UK) & & $\checkmark$ \\
komunitná záhrada Komunitka pre každého (FSEV UK) & & $\checkmark$ \\
\hline
\end{tabular}

Zdroj: vlastný výskum

Aj ked' je vo všeobecnosti primárnou funkciou komunitných záhrad pestovanie plodín (potravín), čo predstavuje významný spôsob udržatel'nosti a zodpovednosti za potravinovú bezpečnost', komunitné záhrady plnia aj iné funkcie. Analýza percepcií členov a správcov komunitných záhrad na území mesta Bratislava preukázal, že primárnou funkciou komunitných záhrad je sociálna funkcia. (Tab. č. 3) Pestovanie vlastných plodín je dôležitá funkcia 
komunitných záhrad, ale často nie primárna. Mnohé komunitné záhrady uprednostňujú sociálnu funkciu budovania spoločenstva, utuženia vzt'ahov alebo využívania priestoru najmä pre mladé rodiny s det'mi. Na otázku „Akým spôsobom vnímate funkciu záhrady" odpovedali správcovia komunitných záhrad nasledovne: „Myslím, že pestovanie je nástroj na sociálne vzt’ahy. To je najväčsi význam záhradky, ale funkciu má aj pestovatel'skú", (správca komunitnej záhrady vo vnútornom meste na mestskom pozemku). „Určite hlavnou funkciou je pestovanie, ale neznamená to, že je to hlavný benefit záhrady. Bez pestovania by sa k nám l'udia nedostali“, (správca rozlohou vel'kej komunitnej záhrady vo vnútornom meste).

\section{Obrázok č. 4: Dôležitost’ členstva v komunitnej záhrade}

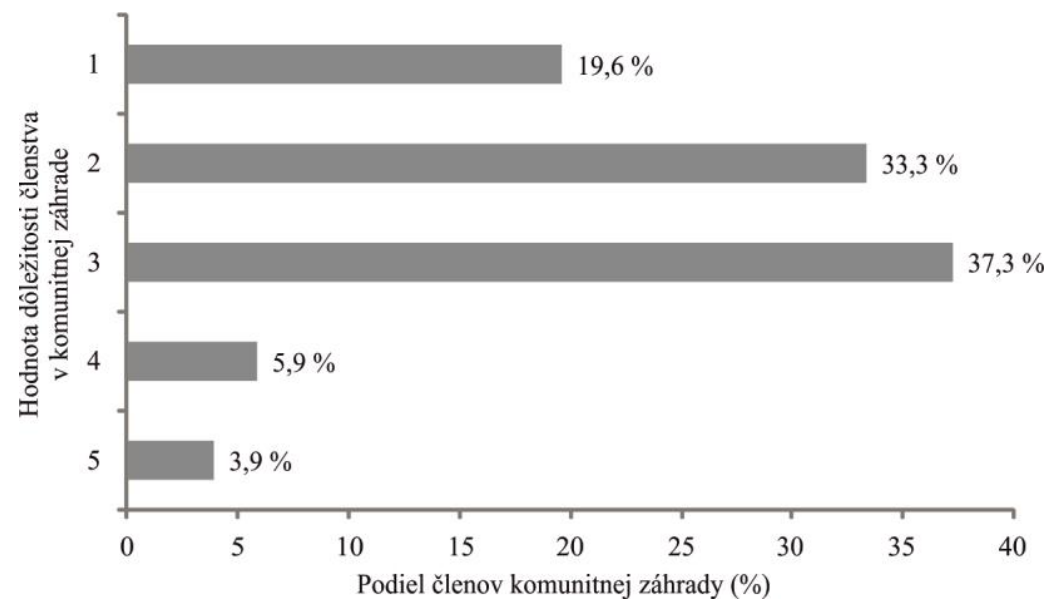

Vysvetlivky: 1 = najviac dôležité, 5 = najmenej dôležité $(\mathrm{n}=51)$

Zdroj: vlastný výskum

Členstvo v komunite možno považovat' za významný benefit komunitných záhrad. Viac ako polovica členov komunitných záhrad hodnotí dôležitost' členstva v komunite vel'mi pozitívne. (Obr. č. 4) „Je dobré vidiet' a stretávat'sa s l'ud’mi s podobnými záujmami ako mám ja“, (muž, 57-ročný). „Pomáha nám spoznat' susedov, trávit's nimi vol’ný čas a pomáhat' si“", (žena, 39-ročná). Dôležitost' členstva najviac pozitívne vnímajú zamestnaní a samostatne zárobkovo činní členovia s priemerným vekom 35 rokov. Pre $43 \%$ členov sa stáva komunitná záhrada miestom trávenia vol’ného času, sociálnym miestom oddychu a rekreácie po práci. Ďalšou početnou skupinou sú členovia na materskej dovolenke, ktorí vnímajú komunitné záhrady ako priestor poskytujúci bezpečné prostredie pre výchovu svojich detí. Komunitné záhrady slúžia pre členov na trávenie vol'ného času, spoznávanie nových priatel'ov a práce v zá- 
hrade vnímajú ako hobby, zábavu. Približne desatina členov však nepovažuje členstvo v komunite za dôležité (hodnoty 4 a 5). Ide väčšinou o členov, ktorí sa na prácach v komunitných záhradách zúčastňujú nepravidelne a majú nadpriemerný príjem: „Do spoločných aktivit sa zapájam málo, 1- až 2-krát ročne. Neprispievam do spoločných diskusii a hlasovani o veciach v záhrade. Takže som komunitne pasivny člen“, (žena, 27-ročná). Funkcie komunitných záhrad sa pre jej členov v čase môžu menit': „Cez materskú som tam bývala viac, popri práci už nestíham, takže záhradka je už pre mňa v úzadí, navyše, bývam dost' d’aleko od nej“, (žena, 29-ročná). Viac ako 2/3 členov komunitných záhrad pozitívne hodnotí vplyv komunitnej záhrady na kvalitu ich života: „Cítime sa viacej súčastou ulice", (žena, 33-ročná).

Ďalšiu funkciu komunitných záhrad možno označit’ ako ekologický spôsob pol’nohospodárstva. $\mathrm{Na}$ pozemkoch komunitných záhrad na území mesta Bratislava v rámci ekologického pestovania až 87,5\% komunitných záhrad využíva kompostovanie a nepoužíva žiadnu chémiu. Princíp permakultúry dodržiavajú štyri komunitné záhrady (komunitná záhrada Vodárenská, komunitná záhrada Pri klube dôchodcov, komunitná záhrada Dobrá mysel', komunitná záhrada Komunitka pre každého). Permakultúra predstavuje systém dizajnu alebo rámec osvedčených postupov na vytváranie a riadenie udržatel'ných a odolných agroekosystémov. Holmgren (2002) definuje permakultúru ako vedome navrhnutú krajinu, ktorá napodobňuje vzorce a vzt’ahy nachádzajúce sa $\mathrm{v}$ prírode a zároveň poskytuje dostatok potravy a energie na zabezpečenie lokálnych potrieb. Je koncepciou navrhovania udržatel'ných sociálno-ekologických systémov využívania pôdy, pričom uznáva, že systémy využívania pôdy sa nikdy neoddel'ujú od sociálnych systémov. (Krebs - Bach 2018) Permakultúru tvorí niekol'ko princípov (Holmgren 2002) a v procese navrhovania a starostlivosti o komunitné záhrady je dôležité používat' princípy ako celok a vytvárat' rovnováhu v systéme. Komunitné záhrady v Bratislave, ktoré prijali princípy permakultúry, sa snažia o organické mulčovanie, zber dažd'ovej vody, výsadbu kvetinových záhonov, výsadbu druhovej diverzity rastlín - diverzitu opel'ovačov, biotopov a diverzifikovaných pol'nohospodárskych rastlín alebo zaobstaranie drevených prvkov v záhradách. Komunitná záhrada Pri klube dôchodcov bola navrhnutá podl'a princípov permakultúry. Odpad recyklujú dve komunitné záhrady (komunitná záhrada v Dúbravke, komunitná záhrada Cyklokuchyňa), t. j. majú zriadený kompostér a nádoby na recykláciu plastov a papiera. Čiastočné používanie chemických hnojív využíva komunitná záhrada v Dúbravke.

Všetky súčasné komunitné záhrady na území mesta Bratislava majú aj rekreačnú funkciu. (Tab. č. 4) Pre 73 \% komunitných záhrad je charakteristická vzorová funkcia, v ktorej prebiehajú workshopy alebo prednášky zamerané na 
pestovatel'ské a technické zručnosti. Edukačnou funkciou sa vyznačuje $64 \%$ komunitných záhrad.

\section{Tabul'ka č. 4: Funkcie komunitných záhrad na území mesta Bratislava}

\begin{tabular}{|c|c|c|c|c|c|}
\hline & $\begin{array}{c}\text { Školská/ } \\
\text { Pedagogická }\end{array}$ & Rekreačná & $\begin{array}{l}\text { Terapeutic- } \\
\text { ká* }\end{array}$ & $\begin{array}{c}\text { Vzorová } \\
* *\end{array}$ & $\begin{array}{c}\text { Edukačná } \\
* * *\end{array}$ \\
\hline komunitná záhrada Vodárenská & & $\checkmark$ & & $\checkmark$ & $\checkmark$ \\
\hline komunitná záhrada Cyklokuchyňa & & $\checkmark$ & & $\checkmark$ & \\
\hline komunitná záhrada Zelená Záhrada & & $\checkmark$ & & & \\
\hline $\begin{array}{l}\text { komunitná záhrada Vinica a mobilná } \\
\text { záhrada Pionierska }\end{array}$ & & $\checkmark$ & & $\checkmark$ & \\
\hline komunitná záhrada Krasňanský zelovoc & & $\checkmark$ & & $\checkmark$ & $\checkmark$ \\
\hline komunitná záhrada Pri klube dôchodcov & & $\checkmark$ & $\checkmark$ & & $\checkmark$ \\
\hline komunitná záhrada Ostredky & & $\checkmark$ & & $\checkmark$ & $\checkmark$ \\
\hline komunitná záhrada Projektu Život & & $\checkmark$ & & $\checkmark$ & \\
\hline $\begin{array}{l}\text { komunitná záhrada a ovocný sad Jedlé } \\
\text { mesto }\end{array}$ & & - & & - & - \\
\hline komunitná záhrada v Dúbravke & & $\checkmark$ & & & $\checkmark$ \\
\hline $\begin{array}{l}\text { komunitná záhrada Dobrá mysel' PRIF } \\
\text { UK }\end{array}$ & $\checkmark$ & $\checkmark$ & & $\checkmark$ & $\checkmark$ \\
\hline $\begin{array}{l}\text { komunitná záhrada } \quad \text { Komunitka } \\
\text { každého (FSEV UK) }\end{array}$ & $\checkmark$ & $\checkmark$ & & $\checkmark$ & $\checkmark$ \\
\hline
\end{tabular}

Vysvetlivky: * Spolupráca so sociálnymi a výchovnými zariadeniami, nemocnicami a iné. ** Prednášky, workshopy, diskusie na tému pestovatel'ských, technických zručností; permakultúra, kompostovanie, ovocinárstvo, vinárstvo, včelárstvo a iné.

*** Spolupráca s vedeckými, vzdelávacími inštitúciami, školami a škôlkami.

Zdroj: vlastný výskum

Aj ked'sú mnohé funkcie komunitných záhrad totožné, bratislavské komunitné záhrady si vzájomne nekonkurujú a zároveň nespolupracujú. Všetci správcovia vzájomnú konkurenciu komunitných záhrad vylúčili (úplne súhlasilo $87,5 \%$, čiastočne súhlasilo $12,5 \%$ správcov). Na druhej strane, v Bratislave nebola zaznamená ani vzájomná spolupráca medzi komunitnými záhradami. Možno preto konštatovat', že komunitné záhrady osobitne vznikajú a vyvíjajú sa. Každá komunitná záhrada je istým spôsobom unikátna: vznikom, prostredím, funkciou, členským zložením, fungovaním a sociálnymi vzt’ahmi. Komunitné záhrady tvoria „živé bunky“ opustených verejných priestorov v meste. Členovia bratislavských komunitných záhrad sú monokomunitní, čiže sú členmi iba jednej komunitnej záhrady ( $96 \%$ členov). 


\section{Diskusia}

Renting et al. (2003) a Milestad et al. (2010) zdôrazňujú sociálny aspekt foriem alternatívnych potravinových sietí, v ktorých sú subjekty súčastou interakcií a procesu od pestovania plodín a produkcie lokálnych potravín, cez cestu potravín k spotrebitel'ovi. DeLind (2002) tvrdí, že ak má komunitná záhrada slúžit' širšej verejnosti (mestskému obyvatel'stvu), tak potom sa mestské pol'nohospodárstvo musí stat' prostriedkom vytvárania lokalít angažovanosti, zmyslu pre príslušnost' komunity a nielen spôsobom, ako dopestovat' potraviny. Členovia komunitných záhrad, jednej z foriem alternatívnych potravinových sietí, sa môžu aktívne zapájat' do mestskej produkcie potravín a lokálnych potravinových systémov a vel'kú čast' svojej produkcie spotrebovat', pričom niektoré komunitné záhrady nadprodukciu potravín využijú pre lokálne trhy a miestne malé obchody.

Komunitné záhrady sú všeobecne považované za istý (alternatívny) spôsob zlepšenia lokálneho prístupu k potravinám. Motivácie na zakladanie komunitnej záhrady sú rôznorodé. (Draper - Freedman 2010; Drake - Lawson 2015; Pourias et al. 2016) Okrem sociálnej angažovanosti a fyzickej aktivity patrí $\mathrm{k}$ dôležitým výhodám členstva $\mathrm{v}$ komunitnej záhrade aj produkcia potravín a snaha o riešenie potravinovej bezpečnosti.

\section{Ide o pestovanie?}

Ponuka komunitných záhrad nie je $\mathrm{v}$ súlade $\mathrm{s}$ dopytom, ked’že počet členov komunít je obmedzený a zdôvodnený počtom boxov alebo obmedzenou plochou na pestovanie. Počty komunitných záhrad každým rokom narastajú. Členovia v komunitách tvoria zaujímavú mozaiku - sú to Bratislavčania s rôznym vekovým zložením (najmladší 23 ročný, najstarší 57 ročný) s prevahou žien. Štvrtina členov komunitných záhrad v Bratislave sú pôvodnými obyvatel'mi Bratislavy, tretinu členov tvoria pristahovaní obyvatelia, ktorí žijú v Bratislave do 10 rokov. Komunitné záhrady vytvárajú priestor pre oddych, rekreáciu, spoznávanie nových l'udí a utuženie vzt'ahov so susedmi. Pre mladé rodiny $\mathrm{s}$ det'mi sú záhrady dôležitou súčast'ou, pretože vytvárajú unikátny priestor pre vývoj detí. Ako uviedol správca komunitnej záhrady vo vnútornom meste na mestskom pozemku: „V Bratislave je obrovský priestor pre vznik záhrad. Dopyt po revitalizácii priestranstiev neustále narastá. V meste je neskutočne vel'ké aktivistické podhubie. Tol'ko l'udí čo chcú a chceli by... stačilo by málo, aby mestá a mestské časti podporili l'udí."

Motivácie lokálnych aktivistov (správcov komunitných záhrad) pre zakladanie komunitných záhrad možno rozdelit' do dvoch skupín. Prvú skupinu charakterizujú motivácie, ktoré vedú $\mathrm{k}$ zmene a rekultivácii priestoru, resp. ide o samotné záhradkárčenie (komunitná záhrada v Dúbravke, komunitná záhrada Zelená záhrada, komunitná záhrada Cyklokuchyňa). Motiváciou druhej 
skupiny je najmä budovanie a rozvoj komunity (komunitná záhrada Vinica a mobilná záhrada Pionierska, komunitná záhrada Krasňanský zelovoc, komunitná záhrada Ostredky, komunitná záhrada Dobrá mysel', komunitná záhrada Komunitka pre každého, komunitná záhrada Pri klube dôchodcov).

Obyvatelia mesta Bratislava chcú vediet' čo konzumujú (jedia). Majú možnost' prispiet' $\mathrm{k}$ udržatel'nosti mesta Bratislava (zvyšovaním mestskej zelene) prostredníctvom vytvárania komunitných záhrad. V čase pestovatel’skej sezóny si členovia vypestujú plodiny priamo vo svojich boxoch v záhradách a vtedy nie sú nútení prispôsobovat' sa konvenčnému nakupovaniu. Komunitné záhrady majú teda aj funkciu zásobovania potravinami. Pestované plodiny (v rámci kolektívneho a individuálneho pestovania) podl'a Spilkovej (2017) možno členit' podl'a kritérií: i) zelenina; ii) ovocie, ovocné stromy; iii) kvetinové záhony; iv) dekoratívne plodiny; v) byliny, liečivé rastliny. V komunitných záhradách v Bratislave je zastúpené pestovanie plodín v každej kategórii. Najrozšírenejšie je pestovanie zeleniny (96\%), kvetinových záhonov (55\%) a ovocných stromov (49\%) so zameraním na pestovanie lokálnych druhov plodín. Plodiny vypestované v komunitných záhradách sa líšia podla klimatických podmienok a špecifických potrieb zelene jednotlivých komunít. (Eizenberg 2012; Middle et al. 2014) Chov zvierat nie je príznačný pre bratislavské komunitné záhrady, iba $\mathrm{v}$ jednej z nich (komunitná záhrada Vodárenská) sú chované zajace a komunitná záhrada Ostredky sa venuje chovu včiel.

Prvotná motivácia, ktorá viedla členov stat' sa súčastou komunitnej záhrady, bola u $79 \%$ členov pestovanie vlastnej, zdravej zeleniny. Iba $25 \%$ členov očakávalo vytvorenie nových vzt’ahov a spoznanie záhradkárov. Pre $10 \%$ členov znamenala záhrada spojenie s prírodou, pre d’alších $10 \%$ (najmä rodičov) predstavovala komunitná záhrada zmysluplné trávenie vol'ného času $\mathrm{s}$ det'mi a zároveň lokalitu, kde sa deti naučia ako správne pestovat' zeleninu a ovocie. „Chcem vypestovat' vlastnú zeleninu, čas strávit' vonku, viest' diet’a k prirode a pestovaniu“, (žena, 32-ročná). „Mestské deti vidia proces pestovania a starostlivosti o rastliny“, (muž, 39-ročný).

\section{Ide o vytváranie komunity?}

Vo všeobecnosti vznikajú komunitné záhrady ako záhradnícke lokality, čiže $\mathrm{s}$ funkciou produkcie potravín (Baker 2004). Tak ako sa potvrdilo aj v prípade Bratislavy, sociálna funkcia sa môže stat' primárnou funkciou komunitnej záhrady. Sociálne benefity vnímajú mnohí správcovia a členovia komunitných záhrad ako výraznú pridanú hodnotu fungovania a existencie komunitnej záhrady. Až sedem z jedenástich správcov komunitných záhrad v Bratislave považuje utužovanie vzt’ahov a budovanie komunity za primárnu funkciu záhrady. Možno konštatovat', že komunitné záhrady zvyšujú interakcie medzi l'ud'mi, ktorí by sa zvyčajne nestretli alebo nespolupracovali. Krasny a Tidball 
(2009) dávajú za príklad komunitné záhrady vo štvrti Bronx v New Yorku, ktoré poskytujú mladým l'ud’om príležitost' učit' sa z praktických poznatkov starších a tým upevňovat' hodnotné spoločenské väzby. V prípade bratislavských komunitných záhrad je členstvo v komunite pre členov dôležité a zároveň ho hodnotia vel'mi pozitívne. Vo všeobecnosti možno súhlasit's autormi Stocker a Barnett (1998) alebo Pudup (2008), podla ktorých majú komunitné záhrady mnoho benefitov, okrem iného podporujú zdravý životný štýl, rozvoj komunity a súdržnost'. Aj ked' dochádza k prelínaniu rôznych funkcií komunitných záhrad, pedagogická, rekreačná, terapeutická, vzorová, edukačná a pod., každá z nich je svojím spôsobom unikátna. Ako uvádzajú Spilková a Rypáčková (2019), komunitné projekty (akými sú aj komunitné záhrady) môžu byt' udržatel'né, ak plnia dôležité sociálne, vzdelávacie a environmentálne potreby (funkcie) obyvatel'ov daných lokalít. Väčšina komunít má stabilnú členskú základňu, ktorá určuje spôsob fungovania komunitnej záhrady, avšak rôzni členovia pristupujú k záujmom a komunite odlišne.

Komunitné záhrady sú nástrojom budovania príslušnosti komunít, aktivizácie a podnietenia angažovanosti členov a riešenia sociálnych tém. (Guitart et al. 2012) Ako uvádza Joy (2014), vytváranie sociálnych vzt’ahov v podobe komunít býva často najzložitejšie. Výskum bratislavských komunitných záhrad poukázal na fakt, že po určitom čase zotrvania vo fungujúcej komunitnej záhrade začnú mat' členovia pocit spolupatričnosti (33\% členov úplne súhlasilo; $49 \%$ čiastočne súhlasilo). Členovia súhlasia, že prostredníctvom komunitnej záhrady sa zlepšujú sociálne vzt’ahy medzi l’ud’mi $(35,3 \%$ úplne súhlasilo; $62,7 \%$ čiastočne súhlasilo). „Vel’a l'udi vraví, že najprv som si myslel, že je to o tých rajčinách a potom som pochopil, že je to o tých l'ud'och. Ja už nepestujem, teším sa, že mám z toho ten sociálny rozmer", (správca rozlohou vel'kej komunitnej záhrady s 11-100 členmi).

Členov väčšiny komunitných záhrad na území mesta Bratislava možno charakterizovat' ako susedov tvoriacich susedskú komunitu (komunitná záhrada Krasňanský zelovoc, komunitná záhrada Pri klube dôchodcov, komunitná záhrada Ostredky, komunitná záhrada Vinica a mobilná záhrada Pionierska, komunitná záhrada Zelená záhrada, Komunitná záhrada v Dúbravke). Až $\mathrm{v}$ troch komunitných záhradách (komunitná záhrada Vodárenská, komunitná záhrada Cyklokuchyňa, komunitná záhrada Projektu život) sú užívatel’mi zamestnanci rovnakej inštitúcie, spoločnosti alebo občianskeho združenia. Väčšina členov trávi svoj vol'ný čas v komunitnej záhrade niekol'kokrát do týždňa (počas sezóny fungovania); 24 \% členov navštívi komunitnú záhradu raz za týždeň. Po skončení prác $\mathrm{v}$ záhrade, vyše polovica členov trávi zvyšok svojho času stretnutím s priatel'mi a susedmi v záhrade, oddychuje a relaxuje. Okrem spoločných nepravidelných brigádnických dní, pridáva záhradám sociálny rozmer aj organizovanie barbecue (piknikov), osláv a posedení, 
spoločných varení (komunitná záhrada Cyklokuchyňa) a čítanie pre deti (komunitná záhrada Ostredky). Členovia komunitných záhrad sa stretávajú pri sezónnych brigádach, športových sútažiach či spoločnom varení. Stolovanie v záhradách sa stáva sociálnym nástrojom súdržnosti komunity a utužovania vzt’ahov. Pri otázke „Ako vnímate členstvo a s ním spojené aktivity v komunitnej záhrade" uviedlo až $47 \%$ členov, že čas strávený v komunitnej záhrade chápe ako trávenie vol’ného času, pričom väčšina $\mathrm{z}$ nich trávi čas $\mathrm{v}$ záhrade niekol'kokrát do týždňa. Zvyšných $35 \%$ respondentov vníma členstvo v komunitnej záhrade ako hobby a $11 \%$ členov ako zábavu.

\section{Ide o otvorený, verejný alebo privátny priestor?}

Komunitné záhrady v Bratislave sa v ponímaní otvoreného priestoru vyznačujú istými špecifikami v porovnaní $\mathrm{s}$ inými komunitnými záhradami v postsocialistickej Európe, západnej Európe alebo USA. Bendt et al. (2013) vysvetl'ujú pojem „verejne prístupné záhrady“ ako záhrady, ktoré sú kedykol'vek otvorené pre všetkých. V prípade Bratislavy nemožno komunitné záhrady chápat' ako „otvorené priestory“ riadené a prevádzkované členmi miestnej komunity. (Evers - Hodgson 2011; Guitart et al. 2012) Bratislavské komunitné záhrady sú charakterizované ako oplotené a uzamknuté záhrady, prístupné iba členom komunity. Fyzické vymedzenie (verejného) priestoru mesta (oplotená a uzamknutá komunitná záhrada) stráca podstatu otvoreného priestoru (pre verejnost'). Zavedenie oplotenia a tým zabránenie prístupu verejnosti do záhrady je vo vel'kej miere závislé od kontextu, v akom sa komunitné záhrady nachádzajú. (Drake - Lawson 2015) O názoroch na oplotenie komunitných záhrad možno diskutovat' z pohl'adu nečlenov alebo členov komunity. Oplotenie komunitnej záhrady môže navodit' pocit prístupovej bariéry, ktorá odrádza potenciálnych nových členov pre vstup do komunity. (Kurtz 2001) Z pohladu členov komunitných záhrad, sprístupnenie záhrad verejnosti môže byt' aj zdrojom sporu. Členovia komunity môžu otvorený prístup verejnosti chápat aj ako zásah do súkromia. (Schmelzkopf 1995) Surls a Director (2001) považujú oplotenie komunitnej záhrady za náležité, najmä pri ochrane pred vandalizmom alebo zvieratami. Až osem z jedenástich komunitných záhrad v Bratislave je oplotených (zamknutých) a slúžia výhradne pre členov komunity, ktorí využívajú pri vstupe kl'úč alebo spoločný kód. Zvyšné komunitné záhrady nie sú oplotené, s prístupom verejnosti a charakterom sa najviac približujú komunitným záhradám definovaných ako otvorený priestor. Priestor v bratislavských komunitných záhradách teda nie je dostatočne využívaný verejnostou a komunitné záhrady v Bratislave nemožno považovat' za otvorené. Tri komunitné záhrady v Bratislave reprezentujú formu „otvorených záhrad“. Je dôležité poznamenat', že iba jedna neoplotená komunitná záhrada $\mathrm{v}$ Bratislave (komunitná záhrada Vinica a mobilná záhrada Pionierska) má problémy s vandaliz- 
mom, iné oplotené záhrady sa nestretli za roky fungovania s takýmito hrozbami. Komunitné záhrady v Bratislave nie sú ohrozené vandalizmom a aj napriek tomu sú oplotené a zamedzujú prístup verejnosti, čo je v rozpore s koncepciou komunitných záhrad. Na druhej strane, v Bratislave vznikajú aj univerzitné komunitné záhrady, ktoré sú prístupné pre širokú verejnost' a charakterom sa najviac približujú komunitným záhradám definovaných ako otvorený priestor.

\section{Ide o lokalitu?}

Poloha komunitných záhrad môže mat' významný vplyv na aktivity komunity. (Bendt et al. 2013) V Bratislave bolo roku 2017 identifikovaných 11 aktívnych komunitných záhrad. Ich priestorové rozloženie na území mesta je nerovnomerné, pričom pre Bratislavu je charakteristická absencia komunitných záhrad v historickom centre mesta, čo však nie je príznačné pre iné mestá. (Napr. Spilková 2017) Príčiny tohto stavu možno zdôvodnit' dvoma spôsobmi. Prvý vychádza z najvyššieho podielu zastavenej plochy v prípade mestskej časti Staré Mesto, ako aj pamiatkovými obmedzeniami, ktoré sú limitujúce pre rozvoj nových komunitných záhrad. Druhý faktor vychádza zo skúsenosti $\mathrm{v}$ minulosti existujúcich komunitných záhrad v centre mesta. Ich zánik súvisí $\mathrm{s}$ vypovedaním nájomnej zmluvy, ked’že pozemky $\mathrm{v}$ centre mesta možno ekonomicky efektívnejšie zhodnotit' iným spôsobom ako záhradníckou činnost’ou. Zároveň možno podotknút', že v mestských častiach lokalizovaných na periférii mesta sa komunitné záhrady takmer nevyskytujú (okrem jednej, v mestskej časti so sídliskovou zástavbou). Ide o mestské časti Jarovce, Rusovce, Čunovo, Devín, Záhorská Bystrica, Vajnory a Podunajské Biskupice, v ktorých prevažuje zástavba rodinných domov s vlastnými záhradami. Aj napriek tomu, že sa komunitné záhrady môžu rozvíjat' aj na periférii alebo vidieku (cf. Guitart et al. 2012), pre obyvatel'ov mesta Bratislava ako potenciálnych členov komunity je klúčová lokalita a percepcie okolia a jeho dostupnost'. Preto sú komunitné záhrady v Bratislave koncentrované do vnútorného mesta.

Z výsledkov výskumu bratislavských komunitných záhrad vyplýva, že vel'kost' komunitnej záhrady daná počtom členov komunity nepodmieňuje spádovú zónu. V Bratislave sú najpočetnejšie komunitné záhrady so základnou spádovou zónou. Delimitácia a charakteristika spádových zón komunitných záhrad sú v literatúre doposial' málo diskutované, aj napriek relevantnosti priestorového prístupu (Wang et al. 2014), čo predstavuje možné smerovanie budúceho výskum komunitných záhrad. 


\section{Záver}

Príspevok je zameraný na klasifikáciu komunitných záhrad na území mesta Bratislava a zhodnotenie ich funkcí́. Ide o prvú komplexnejšiu štúdiu o komunitných záhradách hlavného mesta Slovenska. Možno konštatovat', že za relatívne krátke obdobie rozmachu tohto špecifického spôsobu záhradkárčenia $\mathrm{v}$ postkomunistickom meste si komunitné záhrady našli svoje miesto v skupine obyvatel'ov mesta zameraných na alternatívne potravinové siete.

Komunitné záhrady na území mesta Bratislava nie sú homogénne, naopak sú rôznorodé. Túto rôznorodost' možno analyzovat' podl'a rôznych klasifikačných kritérií. V príspevku sú zhodnotené niektoré z nich (poloha, rozloha, počet členov, vlastnícke pomery). V Bratislave sú komunitné záhrady lokalizované prevažne vo vnútornom meste. Prevládajú rozlohou vel'ké komunitné záhrady a počtom členov stredne vel'ké komunitné záhrady, pričom svoju funkciu plnia prevažne na mestských pozemkoch. Fungovanie komunitných záhrad je závislé od finančných dotácií a dobrovol'ných príspevkov. Väčšina komunitných záhrad pozitívne spolupracuje s mestskými čast’ami (spolupráca spočíva $\mathrm{v}$ povolení užívania a prenajatia pozemku, technickej výpomoci, grantov a dotácií).

Komunitné záhrady v Bratislave poskytujú príležitost' pre sociálne interakcie, vytváranie a premenu priestoru, pričom sociálne a environmentálne motivácie sú mnohokrát dôležitejšie ako záhradnícka produkcia. Tým sa komunitné záhrady v Bratislave neodlišujú od iných. (Saldivar-Tanaka - Krasny 2004; Turner 2011; Nettle 2014; Pourias et al. 2016; Spilkova 2017) Guitart et al. (2012) tvrdia, že komunitné záhrady sú ako „otvorené priestory“ spravované a prevádzkované členmi miestnej komunity, s ciel’om spoločného pestovania plodín alebo kvetov. Nie sú len miestom umožňujúcim mestským obyvatel'om dopestovat' plodiny, ale sú aj nástrojom budovania príslušnosti ku komunite, aktivizácie a podnietenia angažovanosti členov a riešenia sociálnych tém. V akej miere vytvoria l'udia kvalitný verejný priestor, to sa odráža vo vzt'ahoch vo vnútri komunity. Komunita členov sa stretáva s ciel’om združovania, budovania susedských vzt’ahov. Zo sociálneho hl'adiska teda možno komunitnú záhradu považovat' za lokalitu odpočinku, relaxu, formálneho a neformálneho vzdelávania, spoločných znalostí a zručností. Utužovanie vzt’ahu členov záhrady k prírode, osveta o potravinách (plodinách), vytváranie vzt'ahov či priestor na kultúrne podujatia sú vo všeobecnosti hlavnými prínosmi komunitnej záhrady. Rozhodujúcim dôvodom vzniku komunitných záhrad je zoskupovanie, združovanie l’udí s ciel'om spoločného pestovania. Philips (2013) tvrdí, že vedl'ajším produktom pestovania, často dôležitejším ako záhradkárska aktivita, je zoznámenie sa s odlišnými kultúrami, skrášlenie prostredia rozvojom komunity či nadviazanie kontaktov. 
Členov komunitných záhrad funkčne spája najmä pestovanie plodín, čo možno považovat' za dôležitú funkciu všetkých komunitných záhrad. Na druhej strane, členovia aj správcovia komunitných záhrad považujú za nemej dôležitú aj sociálnu funkciu komunitných záhrad, vytváranie komunity. Členstvo v komunite hodnotia členovia komunitných záhrad prevažne pozitívne, čo vplýva aj na kvalitu ich života. Mnohí členovia komunitných záhrad v Bratislave hl'adali lokalitu, kde si môžu vypestovat' svoje vlastné zdravé potraviny a zároveň lokalitu na relax a psychický aj fyzický odpočinok. Komunitné záhrady majú aj d’alšie funkcie: rekreačná, terapeutická, edukačná a pod. Práve edukačná funkcia komunitných záhrad predstavuje potenciál pre uvedomenie si spotreby jednotlivcov a miestnej komunity $\mathrm{v}$ globalizovanom potravinovom systéme, ako aj význam alternatívnych potravinových sietí v tomto systéme. Z vyjadrení správcov komunitných záhrad vyplýva, že počty komunitných záhrad a ich členov každým rokom narastajú, preto možno v budúcnosti očakávat' rozmach zakladania d'alších komunitných záhrad, ako novodobého fenoménu záhradníckej činnosti v urbanizovanom prostredí. Naše zistenia však môžu mat' obmedzenia v súvislosti s použitou metodikou (napríklad výber respondentov) a na potvrdenie alebo rozšírenie súčasných zistení je potrebný d’alší výskum.

Petra Hencelová je doktorandkou na Katedre regionálnej geografie, ochrany a plánovania krajiny Prírodovedeckej fakulty Univerzity Komenského v Bratislave. Výskumne sa orientuje na maloobchod a spotrebu v urbánnom prostredi. Špecializuje sa na alternatívne potravinové siete (komunitné záhrady, farmárske trhy, farmárske obchody, predaj z dvora a pod.) a lokálnu spotrebu.

František Križan pôsobi na Katedre regionálnej geografie, ochrany a plánovania krajiny Prírodovedeckej fakulty Univerzity Komenského v Bratislave. Jeho výskumné aktivity sú zamerané najmä na geografiu maloobchodu a spotreby, geomarketing a nové trendy $v$ geografii so zretelom na zber dát a ich priestorovú analýzu.

Kristína Bilková pôsobí ako samostatná vedecká pracovnícka na Geografickom ústave Slovenskej akadémie vied. Vo svojej výskumnej práci sa zameriava na nákupné správanie spotrebitelov, lokalizáciu maloobchodu a služieb $v$ urbánnom a rurálnom prostredí a ich dostupnost'.

\section{LITERATÚRA}

AGUSTINA, I. - BEILIN, R., 2012: Community Gardens: Space for Interactions and Adaptations. Procedia-Social and Behavioral Sciences 36, s. 439-448. 
ARMSTRONG, D., 2000: A Survey of Community Gardens in Upstate New York: Implications for health promotion and community development. Health \& Place 6, č. 4, s. 319-327.

BAKER, L. E., 2004: Tending Cultural Landscapes and Food Citizenship in Toronto's Community Gardens. Geographical Review 94, č. 3, s. 305-325.

BARTHEL, S. - FOLKE, C. - COLDING, J., 2010: Social-Ecological Memory in Urban Gardens-Retaining the Capacity for Management of Ecosystem Services. Global Environmental Change 20, č. 2, s. 255-265.

BATES, A. J. - SADLER, J. P. - FAIRBRASS, A. J. - FALK, S. J. - HALE, J. D. MATTHEWS, T. J., 2011: Changing bee and Hoverfly Pollinator Assemblages along an Urban-Rural Gradient. PloS one 6, č. 8, s. e23459.

BENDT, P. - BARTHEL, S. - COLDING, J., 2013: Civic Greening and Environmental Learning in Public-Access Community Gardens in Berlin. Landscape and Urban Planning 109, č. 1, s. 18-30.

BITUŠÍKOVÁ, A. - LUTHER, D., 2013: Kultúrna a sociálna diverzita na Slovensku. IV. Spoločenská zmena a adaptácia. Bratislava: Ústav etnológie SAV, Banská Bystrica: ISKŠ FHV UMB, 149 s.

BLOCK, K. - GIBBS, L. - STAIGER, P. K. - GOD, L. - JOHNSON, B. - MACFARLANE, S. - LONG, C. - TOWNSEND, M., 2012: Growing Community: the Impact of the Stephanie Alexander Kitchen Garden Program on the Social and Learning Environment in Primary Schools. Health Education \& Behavior 39, č. 4, s. 419-432.

BORČIĆ, L. S. - CVITANOVIĆ, M. - LUKIĆ, A., 2016: Cultivating Alternative Spaces-Zagreb's Community Gardens in Transition: From Socialist to PostSocialist Perspective. Geoforum 77, s. 51-60.

CLASSENS, M., 2015: The Nature of Urban Gardens: Toward a Political Ecology of Urban Agriculture. Agriculture and Human Values 32, č. 2, s. 229-239.

CORRIGAN, M. P., 2011: Growing what you Eat: Developing Community Gardens in Baltimore, Maryland. Applied Geography 31, č. 4, 1232-1241.

CVEJIĆ, R. - ŽELEZNIKAR, Š. - NASTRAN, M. - REHBERGER, V. - PINTAR, M., 2015: Urban Agriculture as a Tool for Facilitated Urban Greening of Sites in Transition: A Case Study. Urbani izziv 26, s. 84-97.

DAWIDOWICZ, L. - LORENC, M., 2016: Ogród Wilda i Ogród na Placu Wolności. In: Cłapa, T. - Szymański, E. M. (eds.): Nauka dla środowiska, I, Górnołużyckie Stowarzyszenie Pszczelarzy, Zgorzelec, s. 56-67.

DELIND, L. B., 2002: Place, Work, and Civic Agriculture: Common Fields for Cultivation. Agriculture and Human Values 19, č. 3, s. 217-224.

DRÁBEKOVÁ, P. - LAMČKOVÁ, M. - LANGOVÁ, P. - BRONIŠ, P. KANOVSKÁ HALAMOVÁ, J., 2017: Kvalitatívna analýza predstáv zamestnancov a študentov ohl'adom univerzitnej komunitnej záhrady Komunitka. In: Kanovská Halamová, J. (ed.): Komunitná psychológia na Slovensku 2017. Ústav aplikovanej psychológie, Fakulta sociálnych a ekonomických vied. Bratislava: Univerzita Komenského v Bratislave, s. 35-64. 
DRAKE, L. - LAWSON, L. J., 2015: Best Practices in Community Garden Management to Address Participation, Water Access, and Outreach. Journal of Extension 53, č. 6, s. 6FEA3.

DRAPER, C. - FREEDMAN, D., 2010: Review and Analysis of the Benefits, Purposes, and Motivations Associated with Community Gardening in the United States. Journal of Community Practice 18, č. 4, s. 458-492.

DUŽÍ, B. - FRANTÁL, B. - ROJO, M. S., 2017: The Geography of Urban Agriculture: New Trends and Challenges. Moravian Geographical Reports 25, č. 3, s. $130-138$.

EIZENBERG, E., 2013: From the Groud up: Community Gardens in New York City and the Politics of Spatial Transformation. Farnham: Ashgate Publishing Limited, s. 218.

EIZENBERG, E., 2012: Actually Existing Commons: Three Moments of Space of Community Gardens in New York City. Antipode 44, č. 3, s. 764-782.

EVERS, A. - HODGSON, N. L., 2011: Food Choices and Local Food Access Among Perth's Community Gardeners. Loccal Environment 16, č. 6, s. 585-602.

EXNER, A. - SCHÜTZENBERGER, I., 2018: Creative Natures. Community Gardening, Social Class and City Development in Vienna. Geoforum 92, č. June, s. 181195.

FERRIS, J. - NORMAN, C. - SEMPIK, J., 2001: People, Land and Sustainability: Community Gardens and the Social Dimension of Sustainable Development. Social Policy \& Administration 35, č. 5. s. 559-568.

FIRTH, C. - MAYE, D. - PEARSON, D., 2011: Developing "Community" in Community Gardens. Local Environment 16, č. 6, s. 555-568.

GODA, P. - TRENDOV, N. - KIS, M., 2015: Comparative Study on Urban Community Gardening in Central Eastern Europe. In: Nymand-Grarup, A. Gradziuk, K. - Kristensen, N. H. (eds.): Connecting Local and Global Food for Sustainable Solutions in Public Food Procurement. Rome: Proceedings of the Conference, s. 259-260.

GOODMAN, D., 2004: Rural Europe Redux? Reflections on Alternative Agro-Food Networks and Paradigm Change. Sociologia Ruralis 44, č. 1, s. 3-16.

GUITART, D. - PICKERING, C. - BYRNE, J., 2012: Past Results and Future Directions in Urban Community Gardens Research. Urban Forestry \& Urban Greening 11, č. 4, s. 364-373.

HANNA, A. K. - OH, P., 2000: Rethinking Urban Poverty: A Look at Community Gardens. Bulletin of Science, Technology \& Society 20, č. 3, s. 207-216.

HARDIN, P. J. - JENSEN, R. R., 2007: The Effect of Urban Leaf Area on Summertime Urban Surface Kinetic Temperatures: A Terre Haute Case Study. Urban Forestry \& Urban Greening 6, č. 2, 63-72.

HENCELOVÁ, P., 2018: Univerzitné komunitné záhrady. In: Študentská vedecká konferencia PriF UK 2018. Bratislava (Prírodovedecká fakulta Univerzity Komenského v Bratislave), s. 1264-1269.

HOLMGREN, D., 2002: Permaculture - Priciples and Pathways beyond Sustainability. Holmgren Design Services: Victoria, Australia. 
IRVINE, S. - JOHNSON, L. - PETERS, K., 1999: Community Gardens and Sustainable Land Use Planning: A Case-Study of the Alex Wilson Community Garden. Local Environment 4, č. 1, s. 33-46.

JOY, L., 2014: Start a Community Food Garden: The Essential Handbook. Portland: Timber press, s. 204.

KINGSLEY, J. Y. - TOWNSEND, M. - HENDERSON-WILSON, C., 2009: Cultivating Health and Wellbeing: Members' Perceptions of the Health Benefits of a Port Melbourne Community Garden. Leisure studies 28, č. 2, s. 207-219.

KRASNY, M. E. - TIDBALL, K. G., 2009: Community Gardens as Contexts for Science, Stewardship, and Civic Action Learning. Cities and the Environment 2, ̌́. 1, 1-18.

KREBS, J. - BACH, S., 2018: Permaculture - Scientific Evidence of Principles for the Agroecological Design of Farming Systems. Sustainability 10, č. 9, s. 1-24.

KREMEN, C., 2005: Managing Ecosystem Services: What do we Need to Know about their Ecology? Ecology Letters 8, č. 5, s. 468-479.

KURTZ, H., 2001: Differentiating Multiple Meanings of Garden and Community. Urban Geography 22, č. 7, s. 656-670.

MALINOWSKA, A., 2015: Ogrody aktywizujące społeczności. Zieleń Miejska, č. 12, s. $42-44$.

MARTELLOZZO, F. - LANDRY, J. S. - PLOUFFE, D. - SEUFERT, V. ROWHANI, P. - RAMANKUTTY, N., 2014: Urban Agriculture: A Global Analysis of the Space Constraint to Meet Urban Vegetable Demand. Environmental Research Letters 9, č. 6, s. 064025.

MIDDLE, I. - DZIDIC, P. - BUCKLEY, A. - BENNETT, D. - TYE, M. - JONES, R., 2014: Integrating Community Gardens Into Public Parks: An Innovative Approach for Providing Ecosystem Services in Urban Areas. Urban Forestry and Urban Greening 13, č. 4, 638-645.

MILESTAD, R. - WESTBERG, L. - GEBER, U. - BJÖRKLUND, J., 2010: Enhancing Adaptive Capacity in Food Systems: Learning at Farmers' Markets in Sweden. Ecology and Society 15, č. 3, s. 1-18.

MOUGEOT, L. J. A., 2006: Growing Better Cities Urban Agriculture for Sustainable Development. Ottawa: International Development Research Centre, s. 97.

MUDU, P. - MARINI, A., 2018: Radical Urban Horticulture for Food Autonomy: Beyond the Community Gardens Experience. Antipode 50, č. 2, s. 549-573.

NETTLE, C., 2014: Community Gardening as a Social Action. Londýn: Ashgate Publishing, s. 272.

OKVAT, H. A. - ZAUTRA, A. J., 2011: Community Gardening: A Parsimonious Path to Individual, Community, and Environmental Resilience. American Journal of Community Psychology 47, č. 3-4, s. 374-387.

OZER, E. J., 2007: The Effects of School Gardens on Students and Schools: Conceptualization and Considerations for Maximizing Healthy Development. Health Education \& Behavior 34, č. 6, s. 846-863.

PHILIPS, A., 2013: Designing Urban Agriculture: A Complete Guide to the Planning, Design, Construction, Maintenance, and Management of Edible Landscapes. Hoboken: John Wiley \& Sons, s. 276. 
POURIAS, J. - AUBRY, C. - DUCHEMIN, E., 2016: Is Food a Motivation for Urban Gardeners? Multifunctionality and the Relative Importance of the Food Function in Urban Collective Gardens of Paris and Montreal. Agriculture and Human Values 33, č. 2, s. 257-273.

PUDUP, M. B., 2008: It Takes a Garden: Cultivating Citizen-Subjects in Organized Garden Projects. Geoforum 39, č. 3, s. 1228-1240.

RANDOLPH, J., 2011: Environmental Land Use Planning and Management. Washington: Island Press, s. 664.

RENTING, H. - MARSDEN, T. - BANKS, J., 2003: Understanding Alternative Food Networks: Exploring the Role of Short Food Supply Chains in Rural Development. Environment and Planning A 35, č. 3, s. 393-411.

ROCHOVSKÁ, A. - KÁČEROVÁ, M. - ONDOŠ, S., 2014: Výskumné metódy v humánnej geografii a ich aplikácie. Bratislava: Univerzita Komenského.

SALDIVAR-TANAKA, L. - KRASNY, M. E., 2004: Culturing Community Development, Neighborhood Open Space, and Civic Agriculture: The Case of Latino Community Gardens in New York City. Agriculture and Human Values 21, č. 4, s. 399-412.

SAUNDERS, B. - KITZINGER, J., KITZINGER, C., 2014: Anonymising Interview Data: Challenges and Compromise in Practice. Qualitative Research 15, č. 5, s. 616-632.

SCHMELZKOPF, K., 1995: Urban Community Gardens as Contested Space. Geographical Review 85, č. 3, s. 364-381.

SKRZYPCZAK, B. 2016: Ogród sąsiedzki-miejsce które skupia ludzi. Varšava: WIEŚ JUTRA, s. 132.

SMIT, J. - RATTA, A. - NASR, J., 1996: Urban Agriculture: Food, Jobs and Sustainable Cities. New York: United Nations Development Programme, s. 302.

SPILKOVÁ, J., 2016: Alternativní potravinové sítě: Česká cesta. Praha: Karolinum Press, s. 186.

SPILKOVÁ, J., 2017: Producing Space, Cultivating Community: The Story of Prague's New Community Gardens. Agriculture and Human Values 34, č. 4, s. $887-$ 897.

SPILKOVÁ, J. - RYPÁČKOVÁ, P., 2019: Prague’s Community Gardening in Liquid Times: Challenges in the Creation of Spaces for Social Connection. Leisure Studies 38 , č. 4, s. 468-479.

SPILKOVÁ, J. - VÁGNER, J., 2016: The Loss of Land Devoted to Allotment Gardening: The Context of the Contrasting Pressures of Urban Planning, Public and Private Interests in Prague, Czechia. Land Use Policy 52, č. 3, s. 232-239.

SPILKOVÁ, J. - VÁGNER, J., 2017: Food Gardens as Important Elements of Urban Agriculture: Spatio-Developmental Trends and Future Prospects for Urban Gardening in Czechia. Norsk Geografisk Tidsskrift-Norwegian Journal of Geography 72, č. 1, s. 1-12.

STOCKER, L. - BARNETT, K., 1998: The Significance and Praxis of CommunityBased Sustainability Projects: Community Gardens in Western Australia. Local Environment 3, č. 2, s. 179-189. 
SUMNER, J., 2009: Sustainable Horticulture and Community Development: More than just Organic Production. Journal of Sustainable Agriculture 33, č. 4, s. 461-483.

SUPUKA, J. - FERIANCOVÁ, L. - TÓTH, A., 2013: Mestské pol'nohospodárstvo tradície a nové cesty rozvoja. Životné prostredie 47, č. 4, s. 237-241.

SURLS, R. - DIRECTOR, U. C., 2001: Community Garden Start-Up Guide. Los Angeles: University of California Cooperative Extension, s. 6.

SZCZYRBA, Z., 2005: Maloobchod v České republice po roce 1989: vývoj a trendy se zaměřením na geografickou organizaci. Olomouc: Univerzita Palackého, s. 126.

SZULCZEWSKA, B. - CIESZEWSKA, A. - PROVÉ, C., 2013: Urban Agriculture and "Early Birds" Initiatives in Warsaw. Problemy Ekologii Krajobrazu 36, č. 14, s. $155-165$.

SZCZEPAŃSKA, M. - STASZEWSKA, S., 2016: Znaczenie ogrodnictwa miejskiego w procesie rewitalizacji. In: Problemy Rozwoju Miast, č. 3, s. 33-43.

TURNER, B., 2011: Embodied connections: sustainability, food systems and community gardens. In: Local Environment 16, č. 6, s. 509-522.

TURNER, B. - HENRYKS, J. - PEARSON, D., 2010: Community Garden Conference: Promoting Sustainability, Health and Inclusion in the City. In: Proceedings. October 7-8. Belconnen, ACT: Community and School Gardens as Spaces for Learning Social Resilience 77, University of Canberra. Dostupné na: www.canberra.edu.au/communitygardens/attachments/Community-GardenConference-Proceedings.pdf

VIERIKKO, K. - ELANDS, B. - NIEMELÄ, J. - ANDERSSON, E. - BUIJS, A. FISCHER, L. K. - HAASE, D. - KABISCH, N. - KOWARIK, I. - LUZ, A. C. STAHL, A. O. - SZÁRAZ, L. - VAN DER JAGT, A. - KONIJNENDIJK VAN DEN BOSCH, C., 2016: Considering the Ways Biocultural Diversity Helps Enforce the Urban Green Infrastructure in Times of Urban Transformation. Current Opinion in Environmental Sustainability 22, s. 7-12.

VOICU, I. - BEEN, V., 2008: The Effect of Community Gardens on Neighboring Property Values. Real Estate Economics 36, č. 2, s. 241-283.

WALTER, P., 2013: Theorising Community Gardens as Pedagogical Sites in the Food Movement. Environmental Education Research 19, č. 4, s. 521-539.

WANG, H. - QIU, F. - SWALLOW, B., 2014: Can Community Gardens and Farmers' Markets Relieve Food Desert Problems? A Study of Edmonton, Canada. Applied Geography 55, s. 127-137. 